\title{
Dispensation and Liturgy Mediated as an Answer to COVID-19 Restrictions: Empirical Study Based on Polish Online Press Narration
}

\author{
Anna Jupowicz-Ginalska ${ }^{1}$, Marcin Szewczyk ${ }^{2}$, Andrzej Kiciński ${ }^{3}$, Barbara Przywara ${ }^{2}(D)$ and \\ Andrzej Adamski ${ }^{2, *(D)}$
}

1 The Faculty of Journalism, Information and Book Studies, University of Warsaw, 00-310 Warsaw, Poland; a.ginalska@uw.edu.pl

2 College of Media and Social Communication, University of Information Technology and Management, 35-225 Rzeszow, Poland; mszewczyk@wsiz.edu.pl (M.S.); bprzywara@wsiz.edu.pl (B.P.)

3 The Faculty of Theology, John Paul II Catholic University of Lublin, al. Racławickie 14, 20-950 Lublin, Poland; andrzej.kicinski@kul.pl

* Correspondence: aadamski@wsiz.edu.pl

check for

updates

Citation: Jupowicz-Ginalska, Anna, Marcin Szewczyk, Andrzej Kiciński, Barbara Przywara, and Andrzej Adamski. 2021. Dispensation and Liturgy Mediated as an Answer to COVID-19 Restrictions: Empirical Study Based on Polish Online Press Narration. Religions 12: 127. https:// doi.org/10.3390/rel12020127

Academic Editor: Christine A. James

Received: 25 January 2021

Accepted: 12 February 2021

Published: 17 February 2021

Publisher's Note: MDPI stays neutral with regard to jurisdictional claims in published maps and institutional affiliations.

Copyright: (c) 2021 by the authors. Licensee MDPI, Basel, Switzerland. This article is an open access article distributed under the terms and conditions of the Creative Commons Attribution (CC BY) license (https:// creativecommons.org/licenses/by/ $4.0 /)$.

\begin{abstract}
The main objective of this study is to determine the media image of dispensation and liturgy mediated during the COVID-19 pandemic in Poland. The paper is based on interdisciplinary methodology, which combines elements of practical theology (the see-judge-act paradigm) and a communication and media studies approach (media content analysis, critical discourse analysis). The time range of the analysed media discourse is between 12 and 18 March 2020, which was the first week after issuing government restrictions towards liturgy and the Church's response to that: granting the dispensation and supporting the mediatisation of liturgy. The material for the discourse analysis includes online editions of 20 Polish press titles. It occurs that the general attitude of the media towards dispensation and liturgy mediated was positive, but some media tended to present the topics according to their editorial policies. The paper also formulates a theological reflection: although liturgy mediated as a permanent solution could be challenging to accept, it allowed worshippers to experience the liturgy in times of isolation. It is, therefore, an expression of the Church's concern for the health and lives of the faithful, although not entirely in line with the official and long-standing position of the Church towards the mediatisation of the liturgy.
\end{abstract}

Keywords: COVID-19; Poland; Holy Mass; broadcasting; internet; new media; mediatisation; religion; digital religion; mass media studies; pastoral theology; press discourse

\section{Introduction}

The first case of the COVID-19 disease in Poland was officially announced on 4/03/2020. On 12/03/2020, the epidemic emergency was declared and no public, including religious, gathering of more than 50 people was allowed. On 20/03/2020, an epidemic was declared and-among numerous restrictions - the number of participants in religious services was limited to five. These restrictions led to many commentaries as faith/religion issues represent one of the most important topics in Poland: the country remains very religious and the most popular religion is Catholicism (Niedziela.pl/tk 2020). It must be therefore explained that, because of its importance and commonness, only the Catholic context is studied in this paper.

The abovementioned governmental decisions referring to religious gatherings divided Polish society into supporters and opponents of such solutions. The opponents argued that "just as hospitals heal the body, and are not closed (... ), so churches heal the soul, hence they are not to be closed" (DoRzeczy.pl 2020b). They identified ideas to close churches with "succumbing to state power", "turning away from the faithful" and 
"depreciating the Blessed Sacrament" (L24.1t 2020). On the other hand, the supporters suggested that the Church, unlike the entrepreneurs, was treated favourably by the authorities (Tabaka 2020). They also pointed out that churches may cause outbreaks of COVID-19 (Gazetaprawna.pl 2020a; Molga 2020).

The situation was additionally complicated due to the inconsistent reactions of the Church to the pandemic. The spokesman of the Polish Episcopal Conference (Konferencja Episkopatu Polski 2017, hereinafter: KEP) justified the initial idea of increasing the number of church services as "it is inconceivable that the faithful do not pray in churches" (UZ 2020b). The Church authorities often disregarded the epidemic by pointing out greater risks, e.g., "gender ideology"1 (Steinhagen 2020), or argued the effectiveness of collective prayers in the fight against the virus (Chrzczonowicz and Danielewski 2020). On the other hand, there were other examples of bishops' activity, such as warnings against the coronavirus, informing on hygiene principles or reading out the letter from the Ministry of Health (Episkopat.pl 2020a). However, the most important Church reactions were the official stances of the KEP and the Primate of Poland (hereinafter: PP), published on 12/03/2020 - after the announcement of the epidemic emergency.

The first document (Episkopat.pl 2020b) informed about the introduction of preventive measures and recommended that diocesan bishops granted dispensation from the obligation to attend Sunday Mass to the elderly, those with symptoms of infection, children and their caregivers and those who fear the infection. Prayer and "spiritual communication" with the Church community through radio, TV or internet broadcasts "were encouraged" there. The second document confirmed that PP Abp. Polak decreed dispensation from the obligation to attend Sunday Mass (Prymaspolski.pl 2020). In response, the bishops "encouraged the faithful to [ ... ] watch TV broadcasts of masses and services as well as online broadcasts from their parishes", and "priests encouraged their parishioners to use technology to pray so that they could stay at home" (Pastwa 2020, p. 55). In reaction to the noticeable need to support believers, much of the Polish media, including the secular liberal media, decided to broadcast the liturgy ( $\mathrm{Nb}$ 2020). This solution/concept achieved recordhigh popularity ( $\mathrm{pr} / \mathrm{pap} / \mathrm{bg} 2020$ ), i.e., it turned out that $60 \%$ of Poles attended Mass at least once through TV, 21\% through the Internet and 17\% through the radio (Bożewicz 2020, p. 3). Church authorities appreciated the efforts of the media: in mid-March, KEP thanked them for their commitment and the fact that "they prepared extra offers" for the Mass broadcast (Episkopat.pl 2020c). The Episcopate also advised that Mass broadcasts should be arranged through diocesan/parish liturgical celebrations, and in case of difficulties, it encouraged "informing the faithful about national media offers", recommending the list on the KEP website (Episkopat.pl 2020d). It can be stated that proclaiming a state of epidemic brought about a reluctant acceptance of Mass broadcasts as a way of participating in the liturgy. Over time, the Church modified the narrative as the government's restrictions were lifted. The Church came back to emphasising the importance of direct participation in the Eucharist, encouraged people to visit churches and finally cancelled the dispensation.

However, it is very important that in the initial phase of the epidemic, the Church changed, as mentioned, its attitude to virtualised participation in religious rituals. In that context, the period 12-18/03/2020 deserves special attention. Since it includes announcing the stances of the authorities and the Church as well as media coverage throughout the week, it shows how the media presented events which were breakthroughs for the homogeneously religious Polish society. For this reason, the main objective of this paper is to analyse the media reactions to the restrictions referring to religious gatherings and the Church's decisions regarding the restrictions, especially the dispensation and support for liturgy broadcasting, further also referred to as liturgy mediated.

The paper is divided into two parts. The theoretical section refers to the mediatisation of the religion and the Church's stance towards the liturgy mediated. The empirical section

1 In Poland, "gender ideology" is a tool for political and ideological disputes. Ultra-right, ultra-conservative and ultra-Catholic circles associate it, e.g., with aggressive feminism and LGBT+, believing that they threaten traditional Catholic values. 
presents the research methodology and the results of the empirical research. It should be stressed that the text is interdisciplinary: it combines a perspective appropriate for practical theology with communication and media studies, both in the area of theoretical and empirical assumptions.

\section{Literature Review}

\subsection{Mediatisation of Religion}

Hoover (2002, p. 28) claimed that the media and religion intersect, also in terms of scientific reflection. Since both the media and religion are subjects of interest in many scientific disciplines, a multidisciplinary and multidimensional approach can be observed here, which-due to the specificity of theology and its main subject of research-focuses on two perspectives: the theological and the non-theological.

As far as the theological reflection is concerned, the theology of the media and communication should be mentioned above all. Attempts have been made to combine both areas by, e.g., Adamski and Łeccicki (2016); Soukup (2019); Lövheim and Lundmark (2019); Campbell (2013) or Bratosin (2016) (see more in: Adamski et al. 2020).

As regards non-theological reflection, reference should be made to foundational theories, such as the culturalist tradition, mediatisation theory and the social shaping of technology approach (Peterson 2019, p. 1). Among these, the theory of mediatisation comes to the fore, particularly the mediatisation of religion. It is defined as a "two-side process of a highly advanced modernity, where the media (... ) emerge as an independent institution, with its own logic, to which other social institutions must adapt. On the other hand, the media simultaneously become an integral part of different institutions, such as ( ... ) religion, because more and more actions are performed through the interactive mass media" (Hjarvard 2008a, p. 105). Through the processes of mediatisation, religion is becoming increasingly embedded in the logic of the media, both in terms of institutional regulations, symbolic content and individual practices (Hjarvard 2008b, p. 11). Mediatisation of religion, or, in the context of this paper, of liturgy, is a social phenomenon, but like any mediatisation, it is also a social process (Hepp et al. 2015, p. 4; Ampuja et al. 2014). Hepp et al. emphasised it as characteristic of the institutional perspective, which corresponds to the status of the Church. However, this differs from the approach of Krotz (2003, p. 7), for whom mediatisation is indeed a process of socio-cultural change, but which is treated on the level of consequences, while he believes the cause is the development of the media.

Following this path, the mediatisation of the Eucharist should be understood as its virtualised form, transmitted through traditional and non-traditional media. It may have positive consequences, i.e., reaching the faithful with the message, informing them, evangelising them; and negative ones, i.e., trivialisation, erosion of authorities, weakening of community ties, making religious practices superficial (Adamski et al. 2020). Despite the latter, it should be stressed that during the pandemic, it was the media, where the authorities closed the temples or limited the number of participants in the liturgy, that made it possible for the faithful to participate in religious ceremonies on a mass scale. It happened thanks to the Church's acceptance, through the dispensation it granted. It is worth explaining at this point that, under canon law, reasonable, merciful action and loosening of the Church's law is permitted in extraordinary circumstances: the pandemic can be considered an example of this. When it started, the Church in Poland, due to the threat to the health and lives of the faithful, granted a dispensation in all dioceses from the obligation to attend Mass on Sundays and holy days of obligation (Catechism of the Catholic Church 2012, 2181; Codex Iuris Canonic 1983, Can. 87 § 1, Can. 1245 and Can. 1248 § 2) and encouraged the faithful, in accordance with the modern Magisterium of the Church, to participate in it through the radio, television and internet broadcasts (Benedict XVI 2007; Congregazione per il Culto Divino e la Disciplina dei Sacramenti 2020). Given the long evolution of the Church's position on liturgy mediated, this decision must be considered unprecedented. 


\subsection{The Church versus Liturgy Mediated}

Initially, the Church's stance towards the modern press was sceptical: it was manifested, among others, in Gregory XVI's Mirari vos encyclical of 1832, but it softened over time. After the radio was invented and popularised, the Church had to determine its attitude towards it, mainly in terms of real-time sound transmission. A question was raised as to the broadcast of the Eucharist and other religious events. This topic was first mentioned in 1926, when the Abp. of Prague Kordač received a laconic answer from the Holy Office: "Non expedire" ("That is not appropriate"). Two years later, the very same Office called broadcasting attempts an abuse (Szczepaniak 2012, p. 10). In Poland, the first radio transmissions of Holy Masses were carried out on Radio Poznan on Resurrection Sunday and Easter Monday, 17 and 18 April 1927 (Radej 2020). Moreover, on 16/06/1832, Pius XI listened to the broadcast of the Eucharist which concluded the Eucharistic Congress in Dublin and he delivered a live speech to its participants, speaking of his presence at the congress celebrations (Szczepaniak 2012, pp. 9, 16-17). Pius XI also allowed the Spanish, who were unable to attend the Eucharist because of the civil war, to fulfil this duty by listening to broadcasts from the National Radio chapel in Salamanca. Moreover, in 1936, the stance of the Congregation of Rites, which was sent to the Holy Office, endorsed radio Mass broadcast, provided that participation in the radio liturgy does not replace the Sunday obligation to attend Mass, and that the broadcasts do not interweave with inappropriate programmes (Draguła 2009, p. 33; Szczepaniak 2013, pp. 249-55). As for TV broadcasts, such an event happened for the first time during the pontificate of Pius XII: in 1948, on Christmas night, the Catholic Eucharist was broadcast from Notre Dame in Paris and from St. Patrick Cathedral in New York. Pius XII is still regarded today as an enthusiast of television and of using it to preach the Gospel, so the Magisterium of the Church accepted the Eucharist on TV much more easily than on the radio (Draguła 2009, pp. 34-35).

The guidelines for radio and TV broadcasting of church services were first clarified in the De musica sacra et sacra liturgia instruction, issued by the Congregation of Rites on 3/09/1958. A full description and presentation of all documents is provided by Draguła (2009, pp. 37-42). It should be stated that in Poland, the current document regulating these issues is the Directory for the Celebration of the Holy Mass broadcast by television (from 14/03/2017, hereinafter: Directory). This document raises several questions given the pandemic situation. The Directory emphasises that, even for the most pious, listening to a live broadcast of the Eucharist is no substitute for physical participation in it. It highlights three main dimensions of Mass broadcast: pastoral, evangelistic and formative. In the pastoral dimension, broadcasting is a valuable tool for performing the Church's ministry towards the sick, who can "establish spiritual connection with the faithful who are participating in the Eucharist in a particular church, in order to listen to the word of God and to unite their sufferings with the sacrifice of Christ" (Konferencja Episkopatu Polski 2017, n. 8). The evangelistic dimension means taking the Gospel beyond the church walls, while the formative dimension emphasises the need to deliver TV broadcasts in a model way from beautiful churches.

The evangelistic dimension of broadcast during the pandemic was strengthened, as even non-believers or "the unchurched" could seek serenity, solace or answers to questions troubling them in their religious experiences. Thanks to the large number of broadcasts, they were able to choose preachers or contact priests who could provide authority for them. However, the formative dimension, as understood by the Directory, took a back seat-internet broadcasts were far from being technically perfect, and no one considered whether their parish churches met the rigorous architectural and visual standards which had qualified them for TV broadcast before the pandemic. Then, there is the question of television language and being live: the technological and institutional factors applied to broadcasting interfere with the message to such an extent that it is impossible to fully identify the events taking place in reality with their media image (Bartocha 2019, p. 60). The requirement of real-time broadcast is also troublesome, as every medium involves 
the "broadcast delay" (Ruether 2019). All these doubts had to be addressed as a result of the pandemic.

As mentioned, the Church encouraged people to stay at home and use the dispensation, to participate in Mass broadcasts, and to receive Holy Spiritual Communion, preceded by an act of perfect contrition: actions were therefore taken in the opposite direction to the previous ones. Moreover, in the statements of the bishops, there was also an ecclesial thread of building/sustaining of the community through participation in broadcasts. Thus, there was a change in narrative caused by the bishops' care for the spiritual and physical wellbeing of the faithful. With government restrictions, bishops and priests clearly acknowledged that an extraordinary situation requires extraordinary measures to ensure that the faithful are able to communicate spiritually with the community of the Church and participate in sacraments, especially in the Sunday community Eucharist. Therefore, although a broadcast is not a physical presence, it does greatly facilitate spiritual connection, union and being with the community.

Practicing religion in times of the pandemic has already been the subject of scientific analysis. For example, Vermeer and Kregting (2020, p. 1) studied the relationship between religion and the spread of the virus, claiming that "religion probably facilitates the spread of the virus in both a direct and indirect way": "directly through worship services but also indirectly by way of endorsing more general cultural festivities ( ... ) and by strengthening certain non-religious social bonds". Hashmi et al. (2020) highlighted the importance of collaboration between spiritual leaders and healthcare professionals to provide society with a holistic approach to combating COVID-19. A similar perspective, i.e., the importance of faith/religious institutions in collective recovery, was taken by Levin (2020). In Poland, Flasiński (2020) determined the method of presenting topics related to the Catholic Church, and the community on the website of "Gazeta Wyborcza" during the COVID-19 pandemic, in the period from $14 / 01$ to $10 / 10 / 2020$.

Corpuz and Sarmiento (2020, p. 11) studied this issue in the context of Domus ecclesiae (House Church), wondering whether this phenomenon, today associated with the process of virtualisation and digitalisation, can be considered as an "emerging model of a virtual/online Church" - not only currently, but also in the event of similar crises in the future. The concept of the home as a "central category of domestic Christian life" was also studied by Achondo and Eichin (2020), who formulated the term "churchly home".

The role of technology in changing "the collective experience" among American congregations was highlighted by Roso et al. (2020) and Adam et al. (2020), while Oxholm et al. (2020, p. 13) discussed the challenges currently facing New Zealand communities, mentioning, e.g., "the need to mitigate any potential for community transmission" or "difficulties related to social distancing for communal religious practices". The issue of religion virtualisation, viewed also from the perspective of "material absence of physical presence in collective worship" and "psychological presence of that absence", was analysed by Parish (2020), who focused, e.g., on the role of social media in the new pandemic reality.

A media perspective was taken, for example, by Oxholm et al. (2020), who analysed the Facebook profiles of religious communities as well as 31 online media articles referring to religious groups and the pandemic. The topic of liturgy mediated was also explored by Rivera (2020), who examined, for example, evangelical practices on social media. Adam et al. (2020) looked at the internet as a space for worshipping based on four elements: space, time, rite and interaction.

It is worth pointing out that, as has been shown, the links between the epidemic and religion in its broadest sense, with its digitalisation, have already become the subject of scholarly research; still, none of the analysed texts refer to the reaction of the media (and thus the media image) to the dispensation and/or liturgy mediated. Even the interdisciplinary papers focused more on the perspective of the Church and the faithful, with less emphasis on the perspective of the media, which, after all, were not only the providers of the liturgy mediated, but also opinion-forming sources of information about it. This paper, which combines an ecclesiastical and a media point of view, has a chance, firstly, to 
participate in the already established research trend (i.e., the religious aspects of COVID-19) and, secondly, to exploit the emerging research niches, especially in terms of the role of the media in shaping the image of religion and religious leaders.

\section{Materials and Methods}

Our major research goal is to analyse the media reactions to the restrictions referring to religious gatherings and the Church's decisions regarding the restrictions-especially the dispensation and support for liturgy mediated. No hypotheses are formulated because the research is explorative.

As mentioned, this paper combines the methodology of practical theology with that of media studies. The former is inspired by the paradigm of voir-juger-agir (see-judge-act) pastoral theology, developed by Cardijn in 1925 (Britannica 2013), accepted by John XXIII and applied during the Second Vatican Council, especially when drafting the Pastoral Constitution on the Church in the Modern World Gaudium et spes (Vatican Council II 1965).

It should be pointed out that the three-step paradigm in the first phase recognises a specific situation, then, in the light of the Magisterium of the Church, analyses the new signs of the times in order to finally draw conclusions for the Church's current activities.

Contemporary theological studies analysing the Magisterium of the Church show that one component of the media context of the new evangelisation is the Church's openness to the world of the media (Chmielewski 2020). During the COVID-19 pandemic, numerous dispensations from physical participation in the liturgy, followed by its appearance in various media, sparked a full interdisciplinary scholarly debate on the assumptions and implementation of the Church's indications in this area. Therefore, as suggested by the "see" methodology stage, it is necessary to incorporate elements of the media and social communication sciences as well as sociology into pastoral studies so as to obtain the fullest possible grasp of the situation and to try to read the new "signs of the times". In order to recognise them, we need to start from historical reality and analyse current changes in the inability of the faithful to participate directly in the liturgy. At the "judge" stage, it was necessary, though insufficient, to elaborate on the existing teaching of the Church (insufficient, because before COVID-19, no one could have imagined that Christians would not be able to attend Mass, even at Easter, and that bishops would not meet the faithful other than through the media). During the pandemic, the media-not figuratively, but physically-became a real areopagus of Christian presence, offering what the Church holds most precious, namely a visible sign of spiritual communion with the Eucharist celebrated in the church. According to Church teaching, spiritual communion is maintained when the faithful cannot attend Mass directly. Thanks to the broadcasts, it became much easier to establish and maintain this spiritual connection by being able to listen to the sound and see the moving image in real time. This offered the chance to be actively involved (making gestures, saying words) at the same time as the other participants-and this in turn created a greater sense of the aforementioned connection with the community. People need visible signs of an invisible reality - and, with regard to the Mass during the pandemic, broadcasts fulfil this function. This is a completely new situation, which required, on the one hand, an analysis of the media presence of the pastors' messages and, on the other hand, an analysis of what these messages told the faithful about the possibilities of full participation in the spiritual life.

Inspired by the "act" stage, we can only suggest the first possible areas of action, because we are dealing with initial interdisciplinary research carried out during the pandemic. The liturgy of the Church became a media event overnight in the midst of a complex socio-political situation. It entered the "media areopagus", which could neither be immediately evangelised nor simply used as a means of social communication or a tool. Therefore, with the inspiration of the "act" methodology stage, one can indicate what has remained unchanged and what prospects have been opened up for the Church by the pandemic experience, which has made the transition from traditional pastoral care to that of a mediatised community. 
In order to examine the media narrative of liturgy mediated, methods appropriate for communication and media studies were also used: critical discourse analysis and content analysis. Critical discourse analysis seems appropriate for research on press coverage of dynamic social phenomena (van Dijk 2005, pp. 359-60). It helps to identify the element of organising reality and ensuring social order within the discourse, and to determine the hardly visible ties between communication events and a wider context and social and cultural phenomena, reflected in the media communication practice, and thus in a contextually broadly defined discourse (Fairclough 1993). The condition for constructing meanings in the media message is the context, which both reflects and forms a social situation. It is necessary to define the boundaries of the discourse itself and its contextual connections, which allows us to analyse it in a comprehensive way. In this case, the area of the discourse being analysed is the coverage of the online editions of the main Polish press media in the first week of introducing restrictions, concerning restraints on the liturgy, the dispensation and liturgy mediated.

Therefore, a critical approach to the discourse of liturgy mediated is possible according to Couldry and Hepp (2013, p. 197) —for them, the phenomenon of mediatisation involves a two-way influence of culture and changes in media and communication, of a quantitative and qualitative nature (Hepp 2013). The multifacetedness of mediatisation (Strömbäck 2008), which is important from an analytical point of view, is related to the fact that through mediatisation, the media become deeply integrated into the social sphere (Esser and Strömbäck 2014).

The need to define the main features of the discourse allows us to focus on its three main aspects (van Dijk 2006; Hernández-Guerra 2014). This will make it possible to fully explore the relationships between the internal construction of the discourse analysed and the social relations and processes arising from the restrictions imposed on participation in the liturgy (Fairclough 1995, p. 132). It will also help to refer to domination and reflection of power in the discourse and its structure (van Dijk 1993, pp. 249-51; 2005, pp. 354-58) developing along the line between the community of the faithful who wish to enjoy the liturgy (van Dijk 1993, pp. 254-57) and the two-level structure of decision-making power: the state on the higher level and the Catholic Church on the lower one. This, in turn, naturalises the social order and, despite the possible reaction of the media audience, consolidates it (Fairclough 1985). From such a perspective, the part of the dominant discourse (politicians, clergy) that breaks out of the dominant rhetoric is particularly interesting.

The first of the three aspects is the category of language in use. This aspect forms the basis for research on discourse only when we combine a linguistic study (i.e., how and by what linguistic means liturgy broadcasting issues are communicated) with the identification of the communication structure of the media themselves (also in terms of their social and political affiliations and dependencies), their group diversity and individual multifaceted characteristics are we able to identify a sufficiently broad spectrum of analytical discourse exploration. Another aspect of discourse analysis is the idea conveyed by the media. This applies both to the overt idea (usually very easily identifiable and resulting directly from the message) and to the covert one. The research basis here will be to determine both the reasons for the formulation of content that fills the discourse and the grounds for shaping the media (and non-media) social response, always taking into account the ideologised media message, as well as the political, economic, cultural and social basis for shaping the discourse itself. The third aspect, reflected both in the language in use and in the idea conveyed, is social interaction and such a reaction that shapes social reality. Despite such strong connections of this aspect with the previous ones and partial descriptions of this sphere in their analysis, due to its fundamental importance for the critical paradigm of discourse analysis, it should be considered separately, highlighting the way in which press discourse contributes to maintaining and reproducing certain social interactions. 
In our research, we primarily refer to the first two aspects, because the adopted research scope focuses on the content and how it is communicated by the media. A complementary research tool is quantitative content analysis, providing organised data and results from a study carried out on a specific press message (Langer 1997, pp. 6-7). The model use of this type of analysis has been strictly defined in the Polish literature (Pisarek 1983; Lisowska-Magdziarz 2004), although its framework is so broad that it requires precise categorisation of data according to research assumptions.

The analysis designed in this way can provide the answer to the following research questions, combining theological and media studies approaches: (1) What was the media image of the Church's reaction to the restrictions on religious gatherings, dispensation and liturgy mediated?; (2) What similarities and differences were there in the narrative on restrictions, dispensation and liturgy mediated?; (3) Did a new opening in the Church's approach to the celebration of liturgy mediated appear? If so, in what sense and form?

The time range of the discourse is between 12 and 18/03/2020. The discourse analysis material includes online editions of the largest Polish press publications: 7 dailies and 13 weeklies, diversified in terms of worldview and class. Thanks to this, the links between the editorial policies and the media narrative on liturgy mediated can be additionally analysed in an informational and journalistic context (Table 1).

Table 1. Categorisation of the selected press publications.

\begin{tabular}{|c|c|c|c|c|}
\hline Title & $\begin{array}{l}\text { Frequency } \\
\text { - } \quad \text { D (daily) } \\
-\quad \text { (weekly) }\end{array}$ & Online Name & $\begin{array}{ll}\text { Religiousness: } \\
\text { - } & \text { Catholic Media } \\
& \text { (CM) } \\
- & \text { Secular Religious } \\
& \text { Media (SRM) } \\
- & \text { Secular } \\
& \text { Non-Religious } \\
& \text { Media (SNRM) }\end{array}$ & $\begin{array}{ll}\text { Ideological Bias: } \\
- & \text { Left-Wing (L) } \\
- & \text { Liberal (LI) } \\
- & \text { Centrist (C) } \\
- & \text { Conservative } \\
& \text { (CO) } \\
- & \text { Right-Wing (R) } \\
-\quad & \text { No Bias, Tabloid } \\
& \text { (T) }\end{array}$ \\
\hline Gazeta Wyborcza & $\mathrm{D}$ & $\begin{array}{l}\text { Wyborcza.pl + Gazeta.pl } \\
\text { (titles belonging to } \\
\text { Agora's publishing } \\
\text { house, due to the close } \\
\text { content relationships } \\
\text { analysed together) }\end{array}$ & SNRM & LI \\
\hline Fakt & $\mathrm{D}$ & Fakt24.pl & SNRM & $\mathrm{T}$ \\
\hline Super Express & $\mathrm{D}$ & Se.pl & SNRM & $\mathrm{T}$ \\
\hline Rzeczpospolita & $\mathrm{D}$ & Rp.pl & SNRM & $\mathrm{C}, \mathrm{CO}$ \\
\hline Gazeta Prawna & $\mathrm{D}$ & Gazetaprawna.pl & SNRM & C \\
\hline Nasz Dziennik & $\mathrm{D}$ & Naszdziennik.pl & SRM & $\mathrm{R}, \mathrm{CO}$ \\
\hline Trybuna & $\mathrm{D}$ & Trybuna.pl & SNRM & $\mathrm{L}$ \\
\hline Newsweek Polska & $\mathrm{W}$ & Newsweek.pl & SNRM & LI \\
\hline Polityka & $\mathrm{W}$ & Polityka.pl & SNRM & LI, L \\
\hline Wprost & $\mathrm{W}$ & Wprost.pl & SNRM & $\mathrm{C}, \mathrm{CO}$ \\
\hline Sieci & $\mathrm{W}$ & Wsieciprawdy.pl & SNRM & $\mathrm{CO}, \mathrm{R}$ \\
\hline Do Rzeczy & $\mathrm{W}$ & DoRzeczy.pl & SNRM & $\mathrm{CO}, \mathrm{R}$ \\
\hline Gazeta Polska & $\mathrm{W}$ & Gazetapolska.pl & SNRM & $\mathrm{CO}, \mathrm{R}$ \\
\hline Gość Niedzielny & $\mathrm{W}$ & Gosc.pl & $\mathrm{CM}$ & $\mathrm{CO}, \mathrm{R}$ \\
\hline $\begin{array}{l}\text { Tygodnik Katolicki } \\
\text { Niedziela }\end{array}$ & W & Niedziela.pl & $\mathrm{CM}$ & $\mathrm{CO}, \mathrm{R}$ \\
\hline Przewodnik Katolicki & $\mathrm{W}$ & Przewodnik-katolicki.pl & $\mathrm{CM}$ & $\mathrm{CO}, \mathrm{R}$ \\
\hline Idziemy & $\mathrm{W}$ & Idziemy.pl & $\mathrm{CM}$ & $\mathrm{CO}, \mathrm{R}$ \\
\hline Tygodnik Powszechny & $\mathrm{W}$ & Tygodnikpowszechny.pl & SRM & C, LI \\
\hline Tygodnik Przeglad & $\mathrm{W}$ & Tygodnikprzeglad.pl & SNRM & $\mathrm{L}$ \\
\hline Tygodnik NIE & $\mathrm{W}$ & Tygodniknie.pl & SNRM & $\mathrm{L}$ \\
\hline
\end{tabular}


The process of selecting and codifying the media message was based on the assumption that when referring to liturgy mediated during the first week after the introduction of the restrictions, it would strictly address the dispensation and the initiating KEP announcement, which dominated the press discourse on liturgy mediated. Therefore, the main identifying keyword was dispensation, which was used when searching the archives available on press websites, supported by the use of the Google search engine, with a time range set for the results. However, within the codification key and in the case of keyword analysis, their scope was wider and included pandemic and coronavirus cross-combined with restriction, church service, liturgy, Mass, KEP, $P P$, Church, bishops, participation, broadcast. In this way, the discourse was systematised: press articles directly concerning the introduced restrictions on participation in the religious cult were selected and categorised. Codification of the content of the selected press materials based on the categorisation key prepared by the authors of the paper took place in July 2020 and was carried out by a group of students at the UITM in Rzeszów (Poland). Their work was verified by the authors of the paper. The accepted version of the codification results is dated 14/08/2020.

\section{Results, Analysis and Discussion}

The selection criteria were met by 126 articles. The data were presented in the following order: general information; contexts; the media image of the Church's reaction to the restrictions; the media image of the dispensation and liturgy mediated.

\subsection{The Number and Topic Range of the Texts}

At the "see" stage of the pastoral paradigm, it is important to recognise which "media areopaguses" contained information about dispensations.

The differences resulting from the publishing cycle did not affect the number of textsthe dailies and weeklies were similarly interested in the topic regarding the frequency of publication (Table 2). The differences appeared on a detailed level: the left-wing and liberal publications took up the religious theme less frequently than the right-wing/conservative ones. This did not apply to the dailies. Among the socio-political magazines, the Catholic ones and DoRzeczy.pl devoted the most attention to the topic. Among the publications with non-religious themes, the leading ones were the tabloids. In the case of the weeklies, DoRzeczy.pl and Niedziela.pl dominated among the messages with the largest number of non-religious themes, while Gazeta.pl, Gosc.pl, Przewodnik-katolicki.pl and Tygodniknie.pl had the smallest number.

Table 2. The number of texts analysed.

\begin{tabular}{cc}
\hline Medium & Number \\
\hline (Agora) Wyborcza.pl + Gazeta.pl & 13 \\
Fakt24.pl & 15 \\
Gazetaprawna.pl & 7 \\
Naszdziennik.pl & 4 \\
Rp.pl & 15 \\
SE.pl & 12 \\
Trybuna.pl & 1 \\
DoRzeczy.pl & 9 \\
Gazetapolska.pl & 4 \\
Gosc.pl & 7 \\
Idziemy.pl & 8 \\
Newsweek.pl & 4 \\
Niedziela.pl & 8 \\
Polityka.pl & 4 \\
Przewodnik-katolicki.pl & 1 \\
\hline
\end{tabular}


Table 2. Cont.

\begin{tabular}{cc}
\hline Medium & Number \\
\hline Tygodniknie.pl & 1 \\
Tygodnikpowszechny.pl & 5 \\
Tygodnikprzeglad.pl & 1 \\
Wprost.pl & 7 \\
Wsieciprawdy.pl & 0 \\
\hline
\end{tabular}

Source: personal collection.

\subsection{Contexts}

At the "see" and "judge" stages of the pastoral paradigm, an important cognitive element is, apart from learning the publication figures, to distinguish the nature of the different "media areopaguses" which hosted the debate on dispensation and liturgy mediated as a response to COVID-19 restrictions.

In the case of contexts, two aspects were examined (Table 3): (1) whether the message was informative or commenting/publicistic/opinion-forming; and (2) what non-religious contexts were included in the messages.

Table 3. Contextuality-informativeness vs. opinion journalism.

\begin{tabular}{ccc}
\hline Medium & Focus on Information/Pure Information & $\begin{array}{c}\text { Focus on Opinion Journalism/Pure } \\
\text { Opinion Journalism }\end{array}$ \\
\hline (Agora) Wyborcza.pl + Gazeta.pl & 11 & 2 \\
Fakt24.pl & 10 & 5 \\
Gazetaprawna.pl & 5 & 0 \\
Naszdziennik.pl & 2 & 2 \\
Rp.pl & 12 & 3 \\
SE.pl & 3 & 7 \\
Trybuna.pl & 1 & 0 \\
DoRzeczy.pl & 5 & 4 \\
Gazetapolska.pl & 3 & 1 \\
Gosc.pl & 6 & 1 \\
Idziemy.pl & 7 & 1 \\
Newsweek.pl & 0 & 4 \\
Niedziela.pl & 6 & 2 \\
Polityka.pl & 1 & 3 \\
Przewodnik-katolicki.pl & 1 & 0 \\
Tygodniknie.pl & 0 & 1 \\
Tygodnikpowszechny.pl & 1 & 4 \\
Tygodnikprzeglad.pl & 1 & 0 \\
Wprost.pl & 5 & 2 \\
\hline
\end{tabular}

Source: personal collection.

In the case of Gazetaprawna.pl, Rp.pl and Agora's media, the informative approach is dominant (it includes information, comments are only based on quotations, no editorial commentaries). The tabloids, on the other hand, focused on opinion journalism (interview, coverage, reportage, emotional language). It is likely that these dailies went beyond being informative, not so much because of their editorial ideology but because they are not opinion-forming. In the weeklies, it was different: information was dominant in the Catholic magazines, and opinion journalism in the remaining ones (mainly the liberal, liberal/left-wing, left-wing and secular-Catholic media). Thus, it can be assumed that the media narrative is linked to the worldview, with emphasis on the explicit focus of religious periodicals on providing news. 
As regards broadening the messages with additional non-religious contexts (Table 4), they appeared both in informational articles and in opinion journalism (e.g., in quoted/ paraphrased statements, topics or headlines).

Among the publications with non-religious contexts, the leading ones were the tabloids, with Agora and Gazetaprawna.pl media on a smaller scale and Trybuna.pl and Naszdziennik.pl on the smallest scale. In the case of the weeklies, DoRzeczy.pl and Niedziela.pl dominated among the messages with the largest number of contexts, while Gazeta.pl, Gosc.pl, Przewodnik-katolicki.pl and Tygodniknie.pl had the smallest number.

Table 4. Non-religious contexts—character (the numbers do not add up, as one text could have several contexts).

\begin{tabular}{|c|c|c|c|c|c|c|c|c|}
\hline \multirow[b]{2}{*}{ Medium } & \multirow[b]{2}{*}{$\begin{array}{l}\text { Non-Religious } \\
\text { Contexts }\end{array}$} & \multicolumn{3}{|c|}{ Type of Context } & \multicolumn{4}{|c|}{ Tone of Context towards the Church } \\
\hline & & 矛 & . & 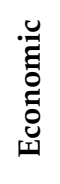 & $\sum_{\substack{\infty \\
0}}^{\infty}$ & 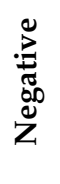 & $\begin{array}{l}\bar{\pi} \\
\bar{Z} \\
\mathbf{Z}\end{array}$ & 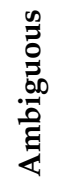 \\
\hline $\begin{array}{c}\text { (Agora) Wyborcza.pl + } \\
\text { Gazeta.pl }\end{array}$ & 7 & 4 & 6 & 1 & 2 & 1 & 0 & 2 \\
\hline Fakt24.pl & 8 & 6 & 4 & 1 & 3 & 2 & 0 & 3 \\
\hline Gazetaprawna.pl & 5 & 2 & 3 & 1 & 3 & 0 & 1 & 1 \\
\hline Naszdziennik.pl & 1 & 1 & 1 & 1 & 0 & 0 & 0 & 1 \\
\hline RP.pl & 4 & 2 & 2 & 1 & 2 & 0 & 1 & 0 \\
\hline SE.pl & 9 & 9 & 1 & 1 & 0 & 4 & 0 & 5 \\
\hline Trybuna.pl & 0 & 0 & 1 & 1 & 0 & 0 & 0 & 0 \\
\hline DoRzeczy.pl & 7 & 4 & 3 & 1 & 4 & 0 & 0 & 4 \\
\hline Gazetapolska.pl & 1 & 1 & 1 & 1 & 0 & 0 & 0 & 1 \\
\hline Gosc.pl & 1 & 1 & 1 & 1 & 0 & 0 & 0 & 0 \\
\hline Idziemy.pl & 4 & 1 & 4 & 1 & 4 & 0 & 0 & 0 \\
\hline Newsweek.pl & 4 & 2 & 3 & 1 & 0 & 2 & 0 & 2 \\
\hline Niedziela.pl & 5 & 1 & 5 & 1 & 3 & 0 & 1 & 0 \\
\hline Polityka.pl & 2 & 3 & 1 & 1 & 1 & 2 & 1 & 0 \\
\hline Przewodnik-katolicki.pl & 1 & 1 & 1 & 1 & 1 & 0 & 0 & 0 \\
\hline Tygodniknie.pl & 1 & 1 & 1 & 1 & 0 & 1 & 0 & 0 \\
\hline Tygodnikpowszechny.pl & 3 & 1 & 3 & 1 & 1 & 1 & 1 & 0 \\
\hline Tygodnikprzeglad.pl & 1 & 0 & 0 & 1 & 0 & 1 & 0 & 0 \\
\hline Wprost.pl & 4 & 1 & 2 & 2 & 0 & 2 & 1 & 1 \\
\hline
\end{tabular}

Source: personal collection.

As far as contexts are concerned, the dailies highlighted political (most strongly in the tabloids) and social (in the opinion-forming media) themes. Economic contexts were the least frequent.

It is the contexts that show the polarised image of the Church. The Catholic and conservative right-wing magazines most often presented a positive approach, while, e.g., Gazetaprawna.pl, Agora's media, Rp.pl and Fakt24.pl were less favourable. The positive information about the Church contained social themes, emphasising the essence of Christian love and encouraging people to help those in need. Fr Janusz Koplewski said: "So let us help each other the best we can (... ). Today alms can be given out remotely" (Ssd 2020), and the Płock bishop appealed: "I am calling on you ( . . . ) to show mercy to the sick and elderly, to show interest and to help them" (Kołodziej 2020). Niedziela.pl (BP/KEP 2020b) and Idziemy.pl (Idziemy.pl/rm 2020) repeated the opinion of the Episcopate and asked for support towards those in need. The media also showed the Church's concern for the health of the faithful and for the community. The Primate of Poland said, "I am thinking of my 82-year-old mother, who is also staying at home, and I would like to set her as an example for other seniors. Let's stay at home" (bgk 2020), and Fr. Prof. Bortkiewicz said that Christians gave "the sick the hope of salvation, love in the work of help and offered the bond of community" (DoRzeczy.pl 2020a). 
The conservative and Catholic magazines avoided presenting the Church in a negative light, and the topics which appeared in other media (e.g., controversial statements of some Church officials) were omitted or presented in a restrained way. The participation of the head of the conservative ruling party (PiS) in the Mass after the declaration of KEP was commented on differently. Gazeta.pl wrote: "While Poland is struggling with an increasing number of infections [ . . ] ], last Sunday Jarosław Kaczyński refused the dispensation given by the bishops" (UZ 2020a). Se.pl claimed that "Jarosław Kaczyński [ . . . ] didn't listen to the bishops!" (CHA and DAB 2020). In contrast, the DoRzeczy.pl (2020a) reassured the public by making it clear that the politician had taken appropriate precautions.

The negative tone towards the government most often appeared in the left-wing and liberal media. Polityka.pl reported that "the current government [ ... ] has been held hostage by the Church and has also had difficulty in taking a clear stance against its obstruction over the epidemic" (Szostkiewicz 2020), and Fakt24.pl asked, "Should the faithful attend masses during the coronavirus epidemic?", answering, "Doctors and scientists have no doubts and keep saying that it is simply unacceptable at such a time!" (teka 2020). The Episcopate's tardiness in announcing the dispensation was criticised ("It is hard to avoid the impression that the Polish Church has exchanged the mastery of souls for the mastery of the offering plate"; Pawlicka 2020), as was the encouragement to participate in masses during the pandemic (Sikora 2020).

The ambiguities shown in the analysis arose from the simultaneous presentation of several differing views in the message, which made it difficult to determine the tone of the context. The methodology of the "judge" stage requires not only thorough research, but also acknowledgement that, sometimes, conclusions must be restrained due to a new, complex contextual situation. Pastoral theology is a discipline which also indicates the limits of reading the "signs of the times" so that they are not hastily overinterpreted.

\subsection{The Media Image of the Church's Reactions to the Restrictions}

The "see" and "judge" stages of pastoral analysis are closely linked in reading the "signs of the times" which are present in the "media areopaguses" during the pandemic restrictions. Without quantitative data, pastoral reflection would remain at the level of relativity. Pastoral theology reflects on the activities of the Church in a pluralistic society which is currently undergoing rapid processes of mediatisation, thus gaining important information from these media studies on the sources and directions of limitations indicated by the media.

Information on restrictions in religious practices appeared in almost all the examined publications (Table 5). It was exposed by the Catholic media and Gazeta.pl/Wyborcza.pl. All the media focused on the restrictions in Poland. The Catholic media never mentioned other countries, except for Niedziela.pl, while in the others, single pieces of information appeared. Only the non-Catholic media raised the issue of South Korea, where religious services were found to facilitate the spread of the disease (teka 2020; Chłopaś 2020). 
Table 5. Media references to restrictions in religious practices.

\begin{tabular}{|c|c|c|c|c|c|c|c|c|}
\hline \multirow[b]{2}{*}{ Medium } & \multirow[b]{2}{*}{ 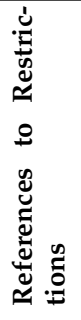 } & \multicolumn{2}{|c|}{ Thread of Restrictions } & \multicolumn{3}{|c|}{ Source of Restrictions Indicated } & \multicolumn{2}{|c|}{ Country of Restrictions } \\
\hline & & 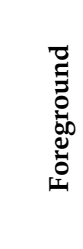 & 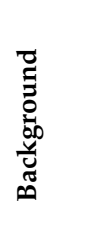 & 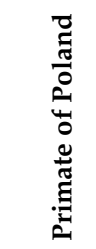 & 武 & 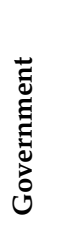 & 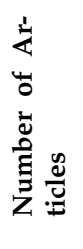 & 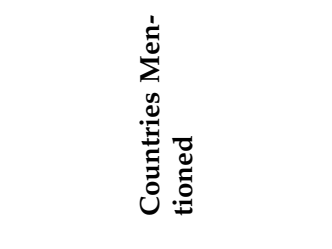 \\
\hline $\begin{array}{c}\text { (Agora) Wyborcza.pl + } \\
\text { Gazeta.pl }\end{array}$ & 12 & 7 & 5 & 0 & 6 & 3 & 12 & $\begin{array}{l}11 \times \text { Poland, Austria, } \\
\text { Germany, Italy, France }\end{array}$ \\
\hline Fakt24.pl & 15 & 7 & 8 & 1 & 7 & 2 & 14 & $\begin{array}{l}14 \times \text { Poland, Vatican, } 2 \times \\
\text { Italy, Belarus, South } \\
\text { Korea }\end{array}$ \\
\hline Gazetaprawna.pl & 6 & 2 & 4 & 0 & 4 & 0 & 6 & $6 \times$ Poland \\
\hline Naszdziennik.pl & 2 & 0 & 2 & 0 & 0 & 0 & 2 & $2 \times$ Poland \\
\hline RP.pl & 14 & 7 & 7 & 0 & 6 & 0 & 14 & $14 \times$ Poland, Italy \\
\hline SE.pl & 10 & 2 & 8 & 0 & 0 & 1 & 10 & $10 \times$ Poland \\
\hline Trybuna.pl & 1 & 0 & 1 & 0 & 0 & 0 & 1 & Poland \\
\hline DoRzeczy.pl & 9 & 3 & 6 & 0 & 3 & 2 & 9 & $9 \times$ Poland \\
\hline Gazetapolska.pl & 1 & 0 & 1 & 0 & 0 & 0 & 1 & Poland \\
\hline Gosc.pl & 6 & 3 & 3 & 0 & 4 & 0 & 6 & $6 \times$ Poland \\
\hline Idziemy.pl & 6 & 5 & 1 & 0 & 3 & 0 & 5 & $6 \times$ Poland \\
\hline Newsweek.pl & 4 & 1 & 3 & 0 & 3 & 0 & 4 & $4 \times$ Poland, South Korea \\
\hline Niedziela.pl & 7 & 4 & 3 & 0 & 3 & 0 & 7 & $6 \times$ Poland, Austria \\
\hline Polityka.pl & 4 & 1 & 3 & 0 & 3 & 2 & 4 & $\begin{array}{c}4 \times \text { Poland, Italy, Czech } \\
\text { Republic, Austria, France, } \\
\text { Slovakia }\end{array}$ \\
\hline Przewodnik-katolicki.pl & 1 & 1 & 0 & 0 & 1 & 0 & 1 & Poland \\
\hline Tygodniknie.pl & 1 & 1 & 0 & 0 & 1 & 0 & 1 & Poland \\
\hline Tygodnikpowszechny.pl & 5 & 3 & 2 & 0 & 3 & 1 & 5 & $4 \times$ Poland, Italy, Austria \\
\hline Tygodnikprzeglad.pl & 0 & 0 & 0 & 0 & 0 & 0 & 0 & 0 \\
\hline Wprost.pl & 6 & 2 & 4 & 0 & 2 & 1 & 1 & $5 \times$ Poland, Italy \\
\hline
\end{tabular}

KEP and the government were acknowledged by all the media as sources of information on the restrictions in the Church-only Fakt24.pl referred to the decree of PP (teka et al. 2020). It is worth pointing out that as far as changes in the mode of ministry are concerned, the magazines, irrespective of their ideological nature, mentioned the postponement of certain ceremonies and community gatherings, the cancellation of pilgrimages and retreats or the rules for organising funerals.

Initially, the liberal media were critical of the Church's negative stance on the limiting/cancellation of masses and the closure of churches (Anderman 2020; Kromer and Wojtczuk 2020). The centric and conservative media tried to justify it: "The idea to close churches [ ... ] is very difficult for the faithful to accept" (Szułdrzyński 2020). The Catholic media defended the bishops' decision: Fr. Szczepaniec argued that "open churches ( . . ) are as necessary as open pharmacies or ( . . ) hospitals" (Fortuna-Sudor 2020).

Research at the "judge" stage reveals that the "media areopaguses" started to differ in their comments on dispensation and liturgy mediated as early as in the first period of the pandemic. This was due to the fact that the press differed in the choice of statements given by the Church authorities (Table 6). 
Table 6. Reactions to the restrictions in the Church (the numbers do not add up, as one text could have several contexts).

\begin{tabular}{|c|c|c|c|c|c|c|}
\hline Medium & $\begin{array}{l}\text { Bishops' } \\
\text { Reaction }\end{array}$ & $\begin{array}{l}\text { Priests' } \\
\text { Reaction }\end{array}$ & $\begin{array}{l}\text { Reaction of the } \\
\text { Faithful }\end{array}$ & $\begin{array}{l}\text { Politicians' } \\
\text { Reaction }\end{array}$ & $\begin{array}{l}\text { Experts' } \\
\text { Reaction }\end{array}$ & $\begin{array}{l}\text { Editorial } \\
\text { Comment }\end{array}$ \\
\hline $\begin{array}{c}\text { (Agora) Wyborcza.pl + } \\
\text { Gazeta.pl }\end{array}$ & 4 & 1 & 1 & 4 & 2 & 2 \\
\hline Fakt24.pl & 7 & 8 & 0 & 3 & 3 & 3 \\
\hline Gazetaprawna.pl & 2 & 0 & 0 & 0 & 2 & 0 \\
\hline Naszdziennik.pl & 0 & 0 & 0 & 0 & 1 & 0 \\
\hline Rp.pl & 2 & 4 & 0 & 2 & 0 & 2 \\
\hline SE.pl & 1 & 3 & 0 & 5 & 0 & 4 \\
\hline Trybuna.pl & 1 & 0 & 0 & 0 & 0 & 0 \\
\hline DoRzeczy.pl & 0 & 1 & 0 & 4 & 2 & 0 \\
\hline Gazetapolska.pl & 0 & 0 & 0 & 0 & 0 & 0 \\
\hline Gosc.pl & 1 & 0 & 0 & 0 & 0 & 1 \\
\hline Idziemy.pl & 2 & 0 & 0 & 0 & 0 & 0 \\
\hline Newsweek.pl & 3 & 2 & 0 & 1 & 2 & 3 \\
\hline Niedziela.pl & 3 & 1 & 0 & 0 & 0 & 0 \\
\hline Polityka.pl & 2 & 1 & 0 & 1 & 0 & 3 \\
\hline Przewodnik-katolicki.pl & 0 & 0 & 0 & 0 & 0 & 0 \\
\hline Tygodniknie.pl & 1 & 1 & 1 & 1 & 0 & 1 \\
\hline Tygodnikpowszechny.pl & 3 & 1 & 1 & 0 & 1 & 4 \\
\hline Tygodnikprzeglad.pl & 0 & 0 & 0 & 0 & 0 & 0 \\
\hline Wprost.pl & 0 & 0 & 0 & 0 & 0 & 0 \\
\hline
\end{tabular}

Source: personal collection.

Agora's media presented an accepting attitude of the Church officials, but this was also negative, as regards the closure of churches: "Abp. Gadecki explained it in an accessible way, as if to someone stupid: >>Just as hospitals heal the ailments of the body, so churches heal the ailments of the soul<<" (Anderman 2020). Likewise, Newsweek.pl did not focus only on the statements of Abp. Ryś: "Please, stay at home. Do not expose yourself or others [... ] to the virus" (Makowski 2020a). It also referred to the words of Abp. Dziega: "Do not be afraid to reach for holy water with faith" (Makowski 2020a), or "Christ does not spread germs or viruses" (Nowak 2020). The juxtaposition of opposing views signalled the lack of a coherent position of the Church towards necessary limitations.

The Catholic media pointed to the priests who complied with the restrictions (Stolfik-Binda 2020; Idziemy.pl/mj 2020a; Kamiński 2020; mag 2020). Niedziela.pl cited the Primate of Poland, who explained that "it is about our safety and health, so that we do not get infected" (bgk 2020). Tygodnikpowszechny.pl presented favourable views of the Church authorities on the restrictions (Sporniak 2020a), but, at the same time, referred to the words of Abp. Dziega, "calling on Catholics to have the courage to use the holy water of which the devil is afraid" (Sporniak 2020b). This last fact was not reported by the analysed Catholic media.

A similar diversity of comments can be seen at the level of the priests' reactions: Wyborcza.pl quoted Fr. Wẹcławski: "Receiving communion in the hand when faced with the coronavirus threat is a sign of lack of faith" (Anderman 2020). Newsweek.pl joined in this narrative, quoting a priest who claimed that "the coronavirus is only one of the threatsthere are other viruses ( . . ) like homosexuality, abortion or euthanasia" (Makowski 2020a). However, the clergy quoted in Polityka.pl gave a calming reminder of the long-standing Church tradition of distributing communion in the hand (Dabrowska et al. 2020), Fakt24.pl (IB 2020) and Se.pl (DR 2020), indicating the clergy's compliance with pandemic conditions. In Rp.pl, the opinion of Fr. Rydzyk, the director of the Catholic Radio Maryja, was an important voice. He made an appeal to "listen to those who know about these matters (... ). We trust in God, but let us not complicate the situation for Him through unwise behaviour" (qm 2020). Rp.pl also gave examples of implementing restrictions by priests all over the country (Krzyżak 2020a; blik 2020). Naszdziennik.pl quoted Fr. Rutkowski: “This is not a time to close churches, but a time to pray and evangelise" (Gajkowski 2020). 
Alongside the positions of the Prime Minister and Minister of Health, the media quoted other words by politicians such as Antoni Macierewicz from PiS ("It is difficult to understand that the Church was chosen as the main enemy [ ... ]. It is simply a disgrace and disgusting and absurd"; Wyborcza.pl, 14/03/2020), the minister Jarosław Gowin ("Please do not expect the government to impose any restrictions on religious communities"; JOSIE 2020) or Radosław Sikorski of the opposition ("As a citizen and a representative of the voters, I demand the suspension of masses like any other type of gathering"; Kromer and Wojtczuk 2020).

As far as media commentators were concerned, the liberal and centrist media cited Prof. Wielgoś, who advocated the closure of churches (Gazetaprawna.pl 2020a; Chłopaś 2020). Naszdziennik.pl, on the other hand, referred to Prof. Ryba, who said: "Denying Catholics the right to attend Mass is like rationing bread" (Kamieniecki 2020). For the sake of balance, DoRzeczy.pl published an opinion formed by Łuczuk PhD: "Going to Mass in the time of $(\ldots)$ the pandemic when we are, for example, sick ( . . ) is in fact not only a threat to others, but also putting God to the test. And we must not do that" (DoRzeczy.pl 2020c).

There is a regularity in the case of editorial comments. The liberal media, supporting restrictions, criticised the behaviour of the Church, raising, for example, issues of its tardiness or the weak position of secular authorities in their relations with the Church officials: "tentative suggestions made by the authorities to give up masses drove a number of Church-affiliated people up the wall" (Anderman 2020). Newsweek.pl believed that "it was only the state of epidemic emergency introduced by the government (...) that forced the Episcopate to make a decision" (Pawlicka 2020), pointing to the behaviour of bishops who are "completely unable to take on the role of responsible religious leaders" (Nowak 2020). Polityka.pl (Szostkiewicz 2020) criticised those in power: "they are strengthening Polish Catholic fundamentalists, who are ready to believe that the coronavirus is the punishment from God". Tygodniknie.pl formulated an opinion, believing that "if the Church continues to be superior to everything and if the President and the Prime Minister do not say boo about Its duties in the time of the epidemic, everything will be a fool's errand" (Mikołajczyk 2020). Fakt24.pl responded in a similar way, asking, "Why this determination of the bishops to risk people's lives and invite them to church despite the deadly threat?" (Makowski 2020b).

A change in views was observed in Tygodnikpowszechny.pl. It initially criticised the attitude of Church officials, describing the words of Abp. Dziegga as "theologically incorrect, empirically false and socially dangerous", closer to "ancient heresies than Catholic orthodoxy" (Sikora 2020). However, it then pointed to the evolution of the bishops' approach to the epidemic, describing KEP's position as "breakthrough" (Sporniak 2020a), and finally recognised that "the Church in Poland has passed the first responsibility exam" (Sporniak 2020b).

The conservative and Catholic media avoided commentary in this area, but Naszdziennik.pl stated that "someone seems to wish for panic to be present" (Kamieniecki 2020). Wprost.pl did not mince words, calling Abp. Gadecki "master" and bishops "employees of his corporation" (Wanat 2020), but also pointed out that "the coronavirus has proved to be an excellent opportunity to feed anti-Catholic phobias" (Kataryna 2020). Only Rp.pl kept the balance. According to them, the latter should realise that "for the faithful, the postulates of closing churches or banning the sacrament is very difficult to accept" (Szułdrzyński 2020), but they believed that the Church should "prepare the faithful well for this undoubtedly difficult time" (Krzyżak 2020b).

\subsection{The Media Image of the Dispensation and Liturgy Mediated}

In the transition from the "see" to the "judge" stage, quantitative and qualitative studies show how the media reflected the image of participation in the liturgy. Reading the "signs of the times" requires a good knowledge not only of the history of salvation but above all of the general Magisterium of the Church as well as the knowledge of activities and theological reflection of other local Churches. 
In the range of numerical representation of the dispensation/liturgy topics, there were no special distinguishable regularities except two: the newspapers referred to the topic more often than the weeklies, and as for the weeklies, it was more often mentioned by the Catholic and conservative ones and Polityka.pl (Table 7).

Table 7. Media references to the dispensation/broadcast of services.

\begin{tabular}{|c|c|c|c|c|c|c|c|c|}
\hline \multirow[b]{2}{*}{ Medium } & \multirow{2}{*}{ 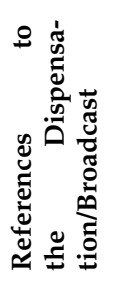 } & \multicolumn{2}{|c|}{$\begin{array}{l}\text { The Dispensation/ } \\
\text { Broadcast Thread }\end{array}$} & \multicolumn{3}{|c|}{$\begin{array}{c}\text { Source of Dispensation/ } \\
\text { Broadcast }\end{array}$} & \multicolumn{2}{|c|}{$\begin{array}{c}\text { Country of Dispensation/ } \\
\text { Broadcast }\end{array}$} \\
\hline & & 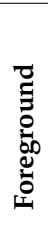 & 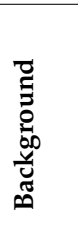 & 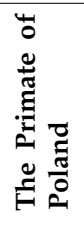 & 武 & 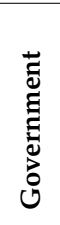 & 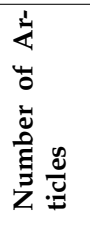 & 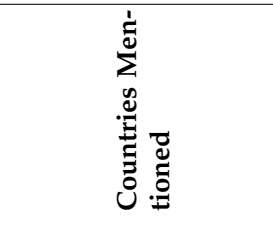 \\
\hline $\begin{array}{c}\text { (Agora) Wyborcza.pl + } \\
\text { Gazeta.pl }\end{array}$ & 13 & 5 & 8 & 0 & 8 & 0 & 13 & $\begin{array}{l}12 \times \text { Poland, Austria, } \\
\text { Germany, France }\end{array}$ \\
\hline Fakt24.pl & 15 & 7 & 8 & 0 & 12 & 0 & 15 & $\begin{array}{l}14 \times \text { Poland, Italy, } \\
\text { Vatican }\end{array}$ \\
\hline Gazetaprawna.pl & 6 & 5 & 1 & 0 & 5 & 1 & 6 & $6 \times$ Poland \\
\hline Naszdziennik.pl & 4 & 3 & 1 & 0 & 2 & 0 & 4 & $4 \times$ Poland \\
\hline RP.pl & 14 & 6 & 8 & 0 & 10 & 0 & 14 & $14 \times$ Poland, Vatican \\
\hline SE.pl & 12 & 3 & 9 & 0 & 2 & 0 & 12 & $12 \times$ Poland, \\
\hline Trybuna.pl & 1 & 0 & 1 & 0 & 0 & 0 & 1 & Poland \\
\hline DoRzeczy.pl & 8 & 3 & 5 & 0 & 2 & 0 & 8 & $4 \times$ Poland \\
\hline Gazetapolska.pl & 4 & 2 & 2 & 0 & 2 & 0 & 4 & $4 \times$ Poland \\
\hline Gosc.pl & 7 & 6 & 1 & 0 & 6 & 0 & 7 & $7 \times$ Poland \\
\hline Idziemy.pl & 8 & 8 & 0 & 0 & 5 & 0 & 8 & $8 \times$ Poland \\
\hline Newsweek.pl & 4 & 1 & 3 & 0 & 3 & 0 & 4 & $\begin{array}{c}4 \times \text { Poland, Italy, } \\
\text { Czech Republic, } \\
\text { Austria, South Korea }\end{array}$ \\
\hline Niedziela.pl & 8 & 8 & 0 & 0 & 5 & 1 & 8 & $7 \times$ Poland, Austria \\
\hline Polityka.pl & 4 & 3 & 1 & 0 & 2 & 1 & 4 & $4 \times$ Poland, Italy \\
\hline $\begin{array}{l}\text { Przewodnik- } \\
\text { katolicki.pl }\end{array}$ & 1 & 1 & 0 & 0 & 1 & 0 & 1 & Poland \\
\hline Tygodniknie.pl & 0 & 0 & 0 & 0 & 0 & 0 & 0 & 0 \\
\hline Tygodnikpowszechny.pl & 5 & 2 & 3 & 0 & 1 & 0 & 5 & $4 \times$ Poland \\
\hline Tygodnikprzeglad.pl & 1 & 0 & 1 & 0 & 0 & 0 & 1 & Poland \\
\hline Wprost.pl & 7 & 3 & 4 & 0 & 2 & 0 & 7 & $6 \times$ Poland, Italy \\
\hline
\end{tabular}

The most frequently cited source of information on the dispensation and broadcast was the stance of the KEP and the decisions of the government, presented as motivating the decisions of the Church. As in the case of the image of the restrictions, the topic of the dispensation/broadcast focused on Poland. Among the Catholic and right-wing conservative media, only Niedziela.pl mentioned other countries, reviewing the Church's activities in Austria.

The frequency with which the media mentioned the dispensation/broadcast was also analysed, as well as which media were indicated as liturgy mediated carriers (Table 8). 
Table 8. References and media vehicles (the numbers do not add up, as one text could have several contexts).

\begin{tabular}{|c|c|c|c|c|c|c|c|}
\hline \multirow[b]{2}{*}{ Medium } & \multicolumn{2}{|c|}{ Number } & \multicolumn{5}{|c|}{ Media Vehicles of Broadcast } \\
\hline & 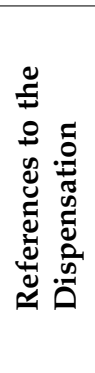 & 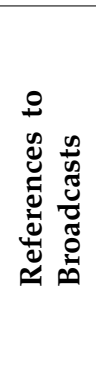 & 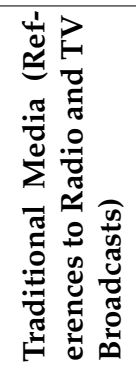 & 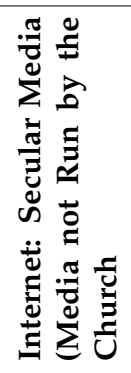 & 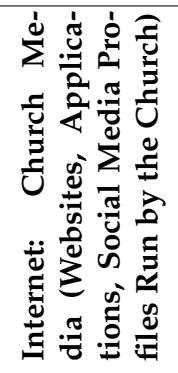 & 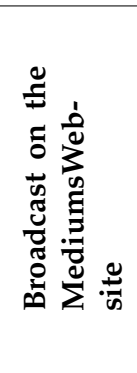 & 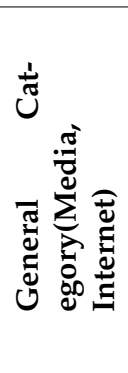 \\
\hline $\begin{array}{c}\text { (Agora) Wyborcza.pl + } \\
\text { Gazeta.pl }\end{array}$ & 13 & 9 & 5 & 2 & 2 & 0 & 7 \\
\hline Fakt24.pl & 15 & 10 & 8 & 1 & 2 & 0 & 4 \\
\hline Gazetaprawna.pl & 5 & 6 & 4 & 1 & 2 & 0 & 4 \\
\hline Naszdziennik.pl & 2 & 3 & 1 & 1 & 1 & 0 & 2 \\
\hline RP.pl & 14 & 13 & 5 & 2 & 3 & 0 & 7 \\
\hline SE.pl & 12 & 7 & 4 & 1 & 1 & 0 & 3 \\
\hline Trybuna.pl & 1 & 1 & 0 & 0 & 0 & 0 & 0 \\
\hline DoRzeczy.pl & 7 & 4 & 2 & 0 & 0 & 0 & 2 \\
\hline Gazetapolska.pl & 4 & 3 & 1 & 1 & 0 & 0 & 2 \\
\hline Gosc.pl & 7 & 5 & 3 & 1 & 2 & 0 & 4 \\
\hline Idziemy.pl & 8 & 8 & 5 & 1 & 4 & 0 & 5 \\
\hline Newsweek.pl & 4 & 3 & 3 & 0 & 0 & 0 & 2 \\
\hline Niedziela.pl & 8 & 8 & 3 & 3 & 3 & 1 & 5 \\
\hline Polityka.pl & 4 & 3 & 2 & 1 & 1 & 1 & 2 \\
\hline $\begin{array}{l}\text { Przewodnik- } \\
\text { katolicki.pl }\end{array}$ & 1 & 1 & 0 & 0 & 0 & 0 & 1 \\
\hline Tygodniknie.pl & 0 & 0 & 0 & 0 & 0 & 0 & 0 \\
\hline Tygodnikpowszechny.pl & 4 & 4 & 4 & 0 & 2 & 0 & 1 \\
\hline Tygodnikprzeglad.pl & 1 & 0 & 0 & 0 & 0 & 0 & 0 \\
\hline Wprost.pl & 5 & 5 & 3 & 1 & 1 & 0 & 3 \\
\hline
\end{tabular}

Source: personal collection.

The dispensation theme appeared more often than the broadcast one; this difference is particularly visible in the Agora's media, the tabloids, DoRzeczy.pl and Gosc.pl. The messages most often referred to broadcasts in the traditional media and in the media/the internet. The articles lack information about the use of the press websites for broadcast, except Niedziela.pl, and it can be stated that the potential of this form of evangelisation was wasted. It should be noted that even if the articles mentioned, for example, the traditional media or the Church media, they did not always provide specific information, such as the name of the medium, the type of service transmitted or its time and place. Most of them remained general, thus not exactly fulfilling the role of a liturgy broadcast communicator. The exceptions were Gazeta.pl, Wprost.pl and Polityka.pl, which informed about the Sunday Mass broadcast on YouTube and Facebook, in the commercial-liberal and conservative, public and Catholic-media (UZ 2020c; Wprost.pl 2020; Zaremba 2020; Dąbrowska et al. 2020).

The Catholic and conservative weeklies informed about liturgy broadcasts in the conservative, Catholic and the public media, which, in Poland, are also right-wing/conservative (Gajkowski 2020; sm 2020; Stolfik-Binda 2020; Idziemy.pl/rm 2020; Idziemy.pl/mj 2020b). They also referred to the Episcopate website and the YouTube channel of the Jasna Góra Monastery. Additionally, Niedziela.pl gave its Facebook profile and website as sources of liturgy mediated (Niedziela.pl 2020).

At the stage of transition from the pastoral paradigm of "judge" to "act", data were obtained which allowed us to perceive and begin to distinguish which "media areopaguses" became open to the new evangelising opportunities connected with Mass broadcasts, and 
which remained at the level of a broadcasting tool. Studying references and media vehicles, it ought to be undoubtedly stated that the evangelistic dimension of broadcast during the pandemic was strengthened, as no previous event had created such a frequent opportunity to participate in the liturgy through such diverse media. Never before had there also been such a public debate on the possibility of dispensation from Mass. Yet, it must also be noticed that many messages remained on a very general level, without the depth of theological or media studies.

Table 9 shows numerically the reactions to the dispensation/broadcasts. As for the reactions of the Church authorities, the articles showed that they were fully supportive. The bishops encouraged the faithful to enjoy the dispensation and experience the liturgy through the media and recommended it to them (e.g., Wyborcza.pl 2020; Gosc.pl 2020; Idziemy.pl/rm 2020; Wprost.pl 2020; Krzyżak 2020a; Pięciak 2020; blik 2020; Mikulski and Zapart 2020; Stolfik-Binda 2020). Church officials reassured the faithful by emphasising that, under dispensation, it is not a sin to miss Sunday Mass (Orłowski et al. 2020); in fact, it is "an expression of concern for the common good and love of God present in another person" (Kołodziej 2020). They also thanked the media and appreciated their support, noting that "the media have offered many broadcasts of Sunday Mass" (POM 2020).

Table 9. Reactions to the dispensation/broadcasts (the numbers do not add up, as one text could have several contexts).

\begin{tabular}{|c|c|c|c|c|c|c|}
\hline Medium & 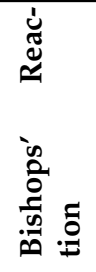 & 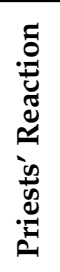 & 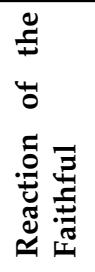 & 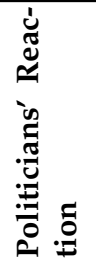 & 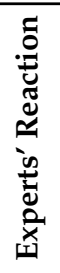 & 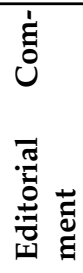 \\
\hline (Agora) Wyborcza.pl + Gazeta.pl & 4 & 1 & 0 & 1 & 0 & 3 \\
\hline Fakt24.pl & 6 & 1 & 0 & 2 & 1 & 1 \\
\hline Gazetaprawna.pl & 2 & 0 & 0 & 1 & 1 & 0 \\
\hline Naszdziennik.pl & 1 & 1 & 1 & 0 & 0 & 1 \\
\hline RP.pl & 6 & 2 & 0 & 1 & 0 & 2 \\
\hline SE.pl & 0 & 0 & 0 & 3 & 0 & 1 \\
\hline Trybuna.pl & 0 & 0 & 0 & 0 & 0 & 0 \\
\hline DoRzeczy.pl & 0 & 0 & 0 & 3 & 1 & 0 \\
\hline Gazetapolska.pl & 0 & 0 & 0 & 0 & 0 & 1 \\
\hline Gosc.pl & 2 & 0 & 0 & 0 & 0 & 0 \\
\hline Idziemy.pl & 5 & 0 & 0 & 0 & 0 & 0 \\
\hline Newsweek.pl & 0 & 0 & 0 & 0 & 0 & 3 \\
\hline Niedziela.pl & 4 & 3 & 0 & 0 & 0 & 0 \\
\hline Polityka.pl & 1 & 1 & 1 & 2 & 0 & 2 \\
\hline Przewodnik-katolicki.pl & 0 & 0 & 0 & 0 & 0 & 0 \\
\hline Tygodniknie.pl & 0 & 0 & 0 & 0 & 0 & 0 \\
\hline Tygodnikpowszechny.pl & 2 & 2 & 0 & 0 & 1 & 1 \\
\hline Tygodnikprzeglad.pl & 1 & 0 & 0 & 0 & 0 & 0 \\
\hline Wprost.pl & 3 & 0 & 0 & 0 & 0 & 0 \\
\hline
\end{tabular}

Source: personal collection.

The Catholic media also quoted positive reactions from the Church authorities, supplementing them with an additional thread: maintaining an appropriate manner of participation. This was pointed out by the PP, who emphasised that "people should not just watch the broadcast; they should truly spiritually join in the celebration, be online rather than offline, doing various other things at the same time" (bgk 2020). Bp. Kamiński also did so: "Holy Masses broadcast by the mass media [ ... ] provide an opportunity for a spiritual experience of the mysteries of faith, which in these extraordinary circumstances can be invaluable for the well-being of the soul and society" (Kamiński 2020). Bp. Bałabuch explained that participation in the broadcast services should be in accordance 
with the recommendations of the Church authorities, i.e., without distracting the faithful or introducing foreign elements. The bishop highlighted the importance of broadcast, so that "the faithful have the opportunity to participate in the Liturgy together with their communities" (Odrobińska 2020). The role of community was emphasised also by Abp. Gądecki (BP/KEP 2020a). A critical attitude towards the Church officials was expressed by the Tygodnikprzeglad.pl, which highlighted the inconsistent position of the Church: "Some bishops announce the dispensation from attendance at Sunday Mass ( . . . ) others want to organise crowded pilgrimages ( ... ) to beg the Blessed Virgin to stop the epidemic" (Widacki 2020).

A positive attitude towards liturgy mediated can be found in the reactions of priests who either provided the broadcast signal or encouraged people to participate in Mass broadcasts (Pięciak 2020; Krzyżak 2020a; blik 2020; Fortuna-Sudor 2020). Understanding was also shown by the cited faithful (Gajkowski 2020), who only from time to time pointed out some technical shortcomings of broadcasts (Dabrowska et al. 2020).

The theme of the politicians' reactions focused on the initiative of Kosma Złotowski from the ruling coalition, who suggested that Sunday offerings be made online. The politician pointed out the drawbacks of the remote service: it is impossible to receive Holy Communion and to make donations (CHA 2020). The government's positions were also quoted, e.g., informing about Mass broadcasts and inviting people to participate in them. The Minister of Health said, "I strongly recommend Mass broadcasts on the radio and television" (KS 2020) and explained that it is "a rightful form of participation in the Mass" (Burzyńska 2020).

Media commentators indicated broadcasts as an alternative to personal participation in Mass (Gazetaprawna.pl 2020b) and stressed the positive role of the dispensation (DoRzeczy.pl 2020d). Tygodnikpowszechny.pl published Rev. Prof. Draguła's warning against uncritical use of remote services: "We would suddenly become a tele-Church, a remote Church, which would, however, be defective because it would be unable to gather in the same place and time [ . . . ]" (Muller and Draguła 2020).

As for the editorial staff's explicit comments on dispensation/liturgy mediated, there are less of them compared to those on restrictions. The media usually displayed a positive or moderate attitude towards the topic. For example, Agora's publications encouraged the Church to support liturgy broadcast more actively: "You have plenty of great social media specialists - and nowadays a standard mobile phone is all you need to broadcast" (Wilgocki 2020). Polityka.pl initially wrote that the Church "can use the dispensation to promote participation in Mass through the mass media and individual prayers" (Szostkiewicz 2020). A few days later, it stated that it is "an unusual situation when bishops (... ) discourage people from visiting churches and encourage them to seek contact with God through the radio and the Internet" (Dabrowska et al. 2020). Newsweek.pl was aloof: it bitterly remarked that "absence at Sunday mass is not a sin. You can sit in front of the TV or computer screen and watch the broadcast" (Pawlicka 2020) and stressed the fact that many various media had joined in liturgy mediated (Makowski 2020a). According to the magazine, "the dispensation has encouraged some of the faithful ( . . ) to attend Mass thanks to television or radio", which means that "there have not been masses in Poland as large as the two unfortunate religious services in South Korea" (Chłopaś 2020).

Balanced opinions were presented by Rp.pl. On the one hand, it pointed out that "bishops could have reacted better and faster", but, at the same time, it had no justification for the "unbelievable hate speech" and "anti-Church obscurantism" that "has crawled out of the depths of the Net". It explained that the sacrament could not be replaced by "watching Mass on TV, although in various situations it is the right thing to do", and it insisted that "Catholics should not be forced to renounce their faith" (Szułdrzyński 2020). A few days later, it concluded that both the faithful and the priests "have passed the responsibility exam" (Krzyżak 2020b). The Catholic media saw the epidemic as an opportunity for evangelisation (Gajkowski 2020) and highlighted the popularity of service broadcasts (Wolski 2020). 
While still at the transition stage from the pastoral paradigm "judge" to "act", we obtained ample data to positively assess the basic message of the Church authorities regarding dispensation and liturgy mediated as a response to COVID-19 restrictions. Empirical data are the key to recognising the "signs of the times".

Media studies have shown that the Church has undertaken and solved tangible problems of present-day believers and seekers. On the one hand, the results of the interdisciplinary research document the enforced transition-related to COVID-19-from traditional to mediated pastoral care. This pastoral service has provided the faithful with the opportunity to participate in broadcast Mass and provided a sense of community in the most difficult moments of loneliness and anxiety. Present-day "media areopaguses" have facilitated spiritual contact with God, other people and individual communities. On the other hand, the empirical research contributes to further theological reflection on the extent to which the Church is rereading the "signs of the times", related to its completely new openness to liturgical celebrations present mainly in the media.

\section{Conclusions}

The above analysis presents the media's image of the Church's decision to introduce restrictions on the direct participation of the faithful in the liturgy mediated during the pandemic. This image proved to be inconsistent on two levels.

The first one is manifested in the fact that it is dependent on ideologised and thus polarised editorial policies.

It has been shown that both in the area of restrictions and in the area of the dispensation/liturgy mediated, the media tended to present the threads according to their editorial policies. It was apparent, particularly in opinion journalism texts, that the liberal and leftwing media are more likely to notice cases of incoherence in the external communication of the Church officials, e.g., inconsistency (change in attitude towards the different stages of the pandemic) and the incoherent narrative (several examples of reckless statements from the Church officials prior to the announcement of official rules, single comments from the clergymen who disagreed with the restrictions and the status given to liturgy broadcasting). They also raised the issue of the Church's insufficient obedience to the secular power, even the lack of responsibility. Information on such cases was consistently and successfully omitted by the conservative and Catholic media, which justified every dubious situation on the grounds of concern of the Church representatives for a truly living community of the faithful. This media category omitted any information on the escalation of the South Korean pandemic in connection with the activities of one of the Churches. They did not refer to the controversial words of bishops either; they were also selective about the lists of media publishing Mass broadcast so as not to include liberal media (while the liberal ones presented both the secular and Catholic media on such lists). The centric publications tried to maintain a relative balance and looked at the problem from various sides.

Nonetheless, in general, and apart from the extremely ideologised cases, it can be said that the overall image of the Church resulting from the full analysed discourse is not a negative one.

The second level of inconsistency in the media's image of the Church was the division of discourse into issues concerning the introduced restrictions and the dispensation. While the first one was connected with a certain chaos and polarised evaluation of it, when it came to the dispensation and its consequences, the picture was positively uniform.

The narrative in the press was very diverse and impulsive, reacting to current events. A certain distance and deeper analysis was presented by Tygodnikpowszechny.pl (presenting the evolution of the official position of the Church) and RP.pl, which, from the beginning, expressed a balanced stance.

Eventually, all the media, albeit to varying degrees, had to admit that the Church, to a certain extent, had complied with the decision of the secular authorities and shifted its consequences to the public, protecting their physical health and, at the same time, soothing the fears arising from their concerns for spiritual health. This is indicated by the social 
context, which appears in the articles the most frequently. Although it appeared mainly in the dailies, it was visible in the majority of the messages, while, at the same time, it was associated with a positive attitude towards the Church and formed a generally positive discourse in this respect. It was perhaps reinforced by the fact that, within the framework of the texts analysed, the economic issue (the idea of online Sunday offering) was not raised by the Church, but by a conservative politician. Therefore, a critical assessment of this solution was not related to the Church officials, but to the secular power.

Despite this diversity of messages, the official position of the Church was reflected in the discourse of all the media. This was also linked to the dominance of information messages over opinion journalism, which was probably due to the fact that the situation was taken seriously and no one wanted to trigger unnecessary violent reactions or fall foul of public opinion. The narrative of the Church built a vision of a spiritual evangelistic message, emphasising the importance of community and religious experience.

The narrow-ranging discourse on the broadcast of services was treated by the media with a great amount of openness, showing the positive attitude of the Church towards liturgy broadcast, and also in the selection of editorial comments and comments of outside experts. This involved the implicit identification of the Church's narrative with that of the secular power, but it was not an obvious and open message. The media accepted responsibility for informing about the possibilities offered by the dispensation and transmission of the Masses. Their narrative in this regard was consistent, although varied in terms of frequency, means of informing and references to sources of sacred message. The Catholic media attached greater importance to informing people about the need to get involved in the liturgy; the liberal media informed about more options, while the conservative and Church media did so selectively, which could have made their audience believe that other media did not broadcast any services. All the media presented the positive attitude of priests towards liturgy broadcast. In this context, the importance of the community and the encouragement to participate in the broadcasts from local parishes were highlighted in a number of ways. It did not matter which media provided the transmissions. At the same time, especially in the Catholic and conservative media, it was pointed out that liturgy broadcast should not be regarded as a permanent substitute for traditional services which are closely associated with being present in places of worship. The role of broadcasting was obviously appreciated, but only because the situation was extraordinary. Warnings were also given that the Church should not become a "tele-Church".

As regards the research questions referring to communication and media studies, it can be said that the media reacted in a variety of ways to the restrictions on religious gatherings and the resulting dispensation and liturgy mediated. They did so in accordance with their ideological attitudes, initially serving their own ideas rather than the audience, mainly in terms of the restrictions. Over time, this approach waned and the narrative became flattened. Instead, the social and human or spiritual contexts dominated. In terms of liturgy mediated itself, although there were minor differences due to the editorial policies, and despite the diversity of the media image, the attitude of the press was positive towards it. As mentioned, the attitude of most of the media towards the Church evolved from initial criticism to acceptance or support.

What is also apparent after a comprehensive analysis is the issue of consolidating the hierarchy of power and naturalising the social order. A coherent duet of secular and Church authorities, visible in the media, consolidated the social order and mutual relations existing in Poland between the public and the secular and Church authorities.

From a pastoral perspective, when analysing the "see" phase, it is worth noting at the general level of the results of the research that restrictions, dispensation and liturgy mediated have become not only an instrument of evangelisation, but also a factor in human development. In the pandemic situation, when Christians felt isolated, virtualised participation in liturgy could strengthen their sense of real unity with the universal community of believers, while the media became a real gift from God (John Paul II 2005; Francis 2014). It must be added that detailed research has shown that the contemporary "media are- 
opaguses" in Poland are highly ideologised. The fact that they have shown a tendency to present religious matters according to their own editorial policies is an important contribution to the thesis that they will later return to the controversial statements of some Church authorities and "exploit" the arguments of the disobedience of the Church when disapproving of or omitting certain pandemic-related restrictions.

On the other hand, when analysing the "judge" phase, one can point out the inconsistent message of the Church about the theological possibilities, but also about the limits of liturgy mediated participation in the Catholic community, which resulted in polarisation of attitudes towards full participation in the life of faith. On the one hand, the Church in Poland vaguely responded to the publications of the Church-independent media, e.g., regarding the violation of restrictions by prominent people, and on the other hand, the Catholic media did not show full acceptance of spiritual communication during liturgy mediated. However, it is important to emphasise the enormous effort made by many communities in organising the liturgy mediated message so as to be close to their followers.

The practice activities of the Church require a good knowledge of given conditions and times. Pastoral theology, through its collaboration with communication and media studies, has received empirical data from the first period of the pandemic on dispensation and liturgy mediated as a response to COVID-19 restrictions on the basis of online press narration. It should be emphasised that communication and media studies, like other social sciences (such as sociology or the sociology of religion), do not describe the entire religious experience, but in their research, they point out connections to social life. Media studies have thus made a valuable contribution, especially to the analysis of media discourse and the extraction of general and detailed elements in terms of communication and complex interactions, especially between the Church and the "media areopaguses". Above all, pastoral theology has received rich sources from interdisciplinary research, which show that society is strongly attached to the Church due to the fact that the Church is deeply rooted in Polish culture. The media have opened up to widespread broadcasting of Mass and other services, and the Church has celebrated the most important faith mysteries through the media. Nevertheless, the analysis showed that even in the very first period of the pandemic, everyone retained their ideological positions. The media analysis also revealed that it was not a good time to deepen the theological issues concerning the celebration of Mass in the media. It was also not the time to deepen the role of dispensation, i.e., exemptions from obligatory provisions of the Church law in extraordinary cases. The media narrative focused on the information that, due to the sharp increase in the number of COVID-19 cases, more and more bishops were recommending that the faithful abstain from Mass and comply with the restrictions. However, there is no thorough theological or canon law reflection on whether these dispensations were necessary at all because of the serious threat to the lives of the faithful and the governmental restrictions, which in fact excluded them from attending Mass (Draguła (2020) was one of the few to refer to this question).

Studies to date do not confirm the interpretation of Mass broadcasting in the media and the associated dispensations from attending it as a particular "sign of the times". They only confirm the unprecedented spread of the broadcast. The results of the research do not claim the right to conclude further theological research in order to read the "signs of the times" in other theological and pastoral areas than those examined here. At this stage of the research, when answering the question concerning how the Church's new openness to the celebration of the liturgy in the media was demonstrated, it should be clearly stated that it was essentially a matter of allowing almost all of the "media areopaguses" to broadcast Mass, along with a large number of broadcasts from individual communities organised on the basis of dispensation and thanks to the encouragement to do so. In the media analysis, the Church continued to treat the media world merely as a means to achieve its objectives; the media also used it as a tool to adjust its programming to the needs of the society.

The analysis of the press narration about the virtualised participation in liturgy at the "act" phase highlighted at least three directions of the Church's activities which 
are worth further discussion. The first is the issue of departing from the hermeneutical language of the canon law contained in dispensation in favour of religious education about the formation of Christian conscience. The second is the need for a coherent voice of the KEP and individual dioceses regarding the chances and dangers of remaining at the level of participation in liturgy digitalised, without a permanent link to the real, tangible community of the Church. The third is the introduction of the subject of media education to priesthood formation and future journalists studying at Church departments (Pontifical Council for Social Communications 2002; Pontifical Council for Promoting the New Evangelization 2020).

It can be therefore stated that media discourse supporting the idea of liturgy mediated can send a clear signal to the Church authorities that the public supports their decisions and accepts them with understanding. This, in turn, may be an argument in favour of a more flexible attitude-if not permanently, then at least for situations such as the COVID-19 pandemic. Developing coherent rules in this area will certainly minimise the information chaos and the fears of the faithful, but it will also reduce criticism towards the Church, thereby contributing to its favourable image in the media.

Author Contributions: Conceptualization: A.J.-G., M.S.; methodology: A.J.-G., A.A., A.K., M.S.; formal analysis: A.J.-G.; resources: M.S., B.P.; writing (original draft preparation): A.J.-G., M.S., A.K., A.A.; B.P.; writing (review and editing): A.J.-G., A.K., A.A.; B.P.; visualisation: A.J.-G.; supervision: A.J.-G. and A.A. All authors have read and agreed to the published version of the manuscript.

Funding: This research received no external funding.

Conflicts of Interest: The authors declare no conflict of interest.

\section{References}

Achondo, Pablo P., and Cristian Eichin. 2020. The Liturgy against the risk of virtuality Effects and ecclesological questions in pandemic times. Teologia y Vida 60: 373-96. [CrossRef]

Adam, Julio C., Iuri A. Reblin, and Marcelo A. Saldanha. 2020. Network church and Liturgy on-line, is it possible? Estudos Teologicos 60: 598-609. [CrossRef]

Adamski, Andrzej, and Grzegorz Łecicki. 2016. Theology and media studies: Interdisciplinarity as a platform for joint reflection on the media. Studia Medioznawcze 1: 11-19. [CrossRef]

Adamski, Andrzej, Anna Jupowicz-Ginalska, and Iwona Leonowicz-Bukała. 2020. Polish Nationwide Catholic Opinion-Forming Weeklies on Social Media-From Theoretical Introduction to Empirical Approach. Religions 11: 190. [CrossRef]

Ampuja, Marko, Juha Koivisto, and Esa Väliverronen. 2014. Strong and Weak Forms of Mediatization Theory. A Critical Review. Nordicom Review 35: 111-23. Available online: https://www.nordicom.gu.se/en/node/35252 (accessed on 15 July 2020 ). [CrossRef]

Anderman, Janusz. 2020. Cymbał Brzmiący albo Dziadek Przewraca się w Grobie. Gazeta Wyborcza. Available online: https: / / wyborcza.pl/7,75968,25791906,cymbal-brzmiacy-albo-dziadek-przewraca-sie-w-grobie.html (accessed on 1 August 2020).

Bartocha, Waldemar. 2019. Liturgia „zmediatyzowana” w świetle Dyrektorium Konferencji Episkopatu Polski w sprawie celebracji Mszy świętej transmitowanej przez telewizję. Łódzkie Studia Teologiczne 28: 55-69.

Benedict XVI. 2007. Sacramentum Caritatis: Post-Synodal Apostolic Exhortation on the Eucharist as the Source and Summit of the Church's Life and Mission. Available online: http:/ /www.vatican.va/content/benedict-xvi/en/apost_exhortations/documents/ hf_ben-xvi_exh_20070222_sacramentum-caritatis.html (accessed on 1 October 2020).

bgk. 2020. Prymas Polski zaleca korzystanie z dyspensy i prosi kapłanów o wyjście do wiernych. Tygodnik Katolicki Niedziela. Available online: https: / / www.niedziela.pl/artykul/50252/Prymas-Polski-zaleca-korzystanie-z (accessed on 6 August 2020).

blik. 2020. Msze bez ludzi, wierni przed telewizorem. Rzeczpospolita. Available online: https://www.rp.pl/Kosciol/303149930-Mszebez-ludzi-wierni-przed-telewizorem.html (accessed on 9 August 2020).

Bożewicz, Marta. 2020. Wpływ pandemii na religijność Polaków. Komunikat z Badań CBOS 74. Available online: https://cbos.pl/ SPISKOM.POL/2020/K_074_20.PDF (accessed on 8 August 2020).

BP/KEP. 2020a. Rada Stała Episkopatu zaleca w kościołach środki ostrożności w związku z koronawirusem. Tygodnik Katolicki Niedziela. Available online: https:/ / www.niedziela.pl/artykul/50122/Rada-Stala-Episkopatu-zaleca-w-kosciolach (accessed on 9 August 2020).

BP/KEP. 2020b. Przewodniczacy Episkopatu podziękował wiernym, księżom i służbom medycznym. Tygodnik Katolicki Niedziela. Available online: https:/ / www.niedziela.pl/artykul/50296/Przewodniczacy-Episkopatu-podziekowal (accessed on 9 August 2020).

Bratosin, Stefan. 2016. La médialisation du religieux dans la théorie du post néo-protestantisme. Social Compass 63: 405-20. [CrossRef]

Britannica. 2013. Young Christian Workers. Available online: https://www.britannica.com/event/Young-Christian-Workers (accessed on 3 September 2020). 
Burzyńska, Agnieszka. 2020. Minister zdrowia o koronawirusie. Predykcje mówią o tysiącu zarażonych na następny tydzień. Fakt. Available online: https: / / www.fakt.pl/wydarzenia / polityka/lukasz-szumowski-o-koronawirusie/4t1hztt?srcc=ucs\&utm_v=2 (accessed on 3 September 2020).

Campbell, Heidi A., ed. 2013. Digital Religion. Understanding Religious Practice in New Media Worlds. New York: Routledge.

Catechism of the Catholic Church. 2012. Second Edition with Modifications from the Editio Typica. Vatican City: Libreria Editrice Vaticana.

CHA. 2020. Zamknęli kościoły. Poseł PiS wie, jak ściagać kasę na tacę. Super Express. Available online: https://www.se.pl/wiadomosci/ polityka/przelej-pieniadze-na-tace-oto-apel-europosla-pis-do-wiernych-aa-qJ7b-nGqg-Gbk9.html (accessed on 2 August 2020).

CHA and DAB. 2020. Jarosław Kaczyński poszedł do kościoła. Nie posłuchał biskupów! Super Express. [ZDJĘCIA]. Available online: https://www.se.pl/wiadomosci/polityka/jaroslaw-kaczynski-poszedl-do-kosciola-nie-boi-sie-koronawirusa-zdjeciaaa-nVjP-YFwM-P1Y1.html (accessed on 2 August 2020).

Chłopaś, Marcin. 2020. Zamknięte oczy, zasłonięte uszy. Biskupi nie chcą trzeźwo spojrzeć na przykład koreański i chronić wiernych przed koronawirusem. Newsweek Polska. Available online: https://www.newsweek.pl/swiat/koronawirus-w-polsce-i-naswiecie-korea-epidemia-koronawirusa-przyspieszyla-po/x9jx6f9 (accessed on 2 August 2020).

Chmielewski, Mirosław. 2020. Media Education and the New Evangelization. Part One: Media Components and Challenges. Verbum Vitae 37: 407-25. [CrossRef]

Chrzczonowicz, Magdalena, and Michał Danielewski. 2020. Będzie wielka msza w Światyni Opatrzności Bożej: Kościół lekceważy koronawirusa w Polsce. OKO.press. Available online: https://oko.press/kosciol-lekcewazy-koronawirusa-w-polsce/ (accessed on 11 March 2020).

Codex Iuris Canonici. 1983. Vatican City: Libreria Editrice Vaticana.

Congregazione per il Culto Divino e la Disciplina dei Sacramenti. 2020. Decree: In time of Covid-19. Available online: http:/ /www. vatican.va/roman_curia/congregations /ccdds/documents/rc_con_ccdds_doc_20200325_decreto-intempodicovid_en.html (accessed on 3 September 2020).

Corpuz, Jeffe C. G., and Philip J. D. Sarmiento. 2020. Going back to basics: Experiencing Domus ecclesiae (House Church) in the celebration of the Liturgy during COVID-19. Practical Theology. [CrossRef]

Couldry, Nick, and Andreas Hepp. 2013. Conceptualizing mediatization. Communication Theory 23: 191-202. [CrossRef]

Dąbrowska, Anna, Paweł Reszka, and Mariusz Sepioło. 2020. „Bóg jest dostępny przez radio”. Niedziela w pustych kościołach. Polityka. Available online: https:/ / www.polityka.pl/tygodnikpolityka/kraj/1946806,1,bog-jest-dostepny-przez-radio-niedzielaw-pustych-kosciolach.read (accessed on 1 August 2020).

DoRzeczy.pl. 2020a. Ks. prof. Bortkiewicz: Eucharystia jest pokarmem, ale i lekarstwem. Do Rzeczy. Available online: https: / / dorzeczy.pl/kraj/132546/ks-prof-bortkiewicz-eucharystia-jest-pokarmem-ale-i-lekarstwem.html (accessed on 2 August 2020).

DoRzeczy.pl. 2020b. Terlikowski: Dzięki Bogu rząd nie może zamykać kościołów. Do Rzeczy. Available online: https: / / dorzeczy.pl/ kraj/132372/terlikowski-dzieki-bogu-rzad-nie-moze-zamykac-kosciolow.html (accessed on 11 March 2020).

DoRzeczy.pl. 2020c. Ekspert: Sytuacja jest groźna. Ktoś postanowił zasiać panikę wśród Polaków. Do Rzeczy. Available online: https:/ / dorzeczy.pl/kraj/132723/ekspert-sytuacja-jest-grozna-ktos-postanowil-zasiac-panike-wsrod-polakow.html (accessed on 3 August 2020).

DoRzeczy.pl. 2020d. Transmisje niedzielnych nabożeństw w mediach. Wierni zadowoleni z dyspensy? Do Rzeczy. Available online: https:/ / dorzeczy.pl/kraj/132721/transmisje-niedzielnych-nabozenstw-w-mediach-wierni-zadowoleni-z-dyspensy.html (accessed on 1 August 2020).

DR. 2020. Ważny kościół w Warszawie podjął trudną decyzję. Ultrakatolikom to się nie spodoba. Super Express. Available online: https:/ / www.se.pl/wiadomosci/polska/wazny-kosciol-w-warszawie-zawiesza-msze-aa-inyo-XTRV-xQjn.html (accessed on 3 August 2020).

Draguła, Andrzej. 2009. Eucharystia zmediatyzowana. Teologiczno-pastoralna interpretacja transmisji Mszy Świętej w radiu i telewizji. Zielona Góra: Wydawnictwo Diecezji Zielonogórsko-Gorzowskiej.

Draguła, Andrzej. 2020. Powrót na Mszę, czyli kłopoty z dyspensa. “Więź” z 03.06.2020. Available online: http://wiez.com.pl/2020/0 6/03/powrot-na-msze-czyli-klopoty-z-dyspensa/\#_ftn1 (accessed on 17 November 2020).

Episkopat.pl. 2020a. Komunikat Przewodniczacego Konferencji Episkopatu Polski. Available online: https://episkopat.pl/ przewodniczacy-episkopatu-stosujmy-sie-rozporzadzenia-organow-panstwowych-by-na-mszy-sw-w-kosciolach-przebywalodo-50-osob-2/ (accessed on 13 March 2020).

Episkopat.pl. 2020b. Zarządzenie nr 1/2020 Rady Stałej Konferencji Episkopatu Polski z dnia 12 marca 2020 r. Available online: https:/ / episkopat.pl/zarzadzenie-nr-1-2020-rady-stalej-konferencji-episkopatu-polski-z-dnia-12-marca-2020-r/ (accessed on 12 March 2020).

Episkopat.pl. 2020c. Orędzie telewizyjne Przewodniczącego Konferencji Episkopatu Polski. Available online: https: / episkopat.pl/ abp-gadecki-zachecam-do-korzystania-z-dyspensy-od-uczestnictwa-w-niedzielnej-mszy-sw-2/ (accessed on 14 March 2020).

Episkopat.pl. 2020d. Wskazania dla biskupów odnośnie do sprawowania czynności liturgicznych w najbliższych tygodniach. Available online: https:/ / episkopat.pl/prezydium-episkopatu-przypominamy-o-koniecznosci-udzielenia-kolejnej-dyspensy-2/ (accessed on 25 March 2020).

Esser, Frank, and Jesper Strömbäck. 2014. Introduction. Making sense of the mediatization of politics. Journalism Studies 15: $243-55$.

Fairclough, Norman L. 1985. Critical and Descriptive Goals in Discourse Analysis. Journal of Pragmatics 9: 739-63. [CrossRef] 
Fairclough, Norman L. 1993. Critical Discourse Analysis and the Marketisation of Public Discourse: The Universities. Discourse $\mathcal{E}$ Society 4: 133-68.

Fairclough, Norman L. 1995. Critical Discourse Analysis: The Critical Study of Languages. London: Longman.

Flasiński, Krzysztof. 2020. Kościół katolicki i jego społeczność na łamach serwisu internetowego „Gazety Wyborczej” podczas epidemii COVID-19. Kultura-Media-Teologia 43: 65-87. [CrossRef]

Fortuna-Sudor, Maria. 2020. To szczególne rekolekcje. Tygodnik Katolicki Niedziela. Available online: https://www.niedziela.pl/ artykul/50339/To-szczegolne-rekolekcje (accessed on 6 August 2020).

Francis. 2014. Message of Pope Francis for the 48th World Communications Day Communication AT the Service of an Authentic Culture of Encounter. Available online: http://w2.vatican.va/content/francesco/en/messages/communications/documents/ papa-francesco_20140124_messaggio-comunicazioni-sociali.html (accessed on 3 September 2020).

Gajkowski, Krzysztof. 2020. Boża szczepionka. Nasz Dziennik. Available online: https://wp.naszdziennik.pl/2020-03-14 (accessed on 9 August 2020).

Gazetaprawna.pl. 2020a. Rektor WUM apeluje o zamknięcie kościołów. "Być może unikniemy porażającej liczby 28 tysięcy chorych". Gazeta Prawna. Available online: https://www.gazetaprawna.pl/artykuly/1459376,koronawirus-pandemia-czy-koscioly-bedazamkniete.html (accessed on 12 March 2020).

Gazetaprawna.pl. 2020b. Pinkas: Rekomendujemy, żeby modlić się w domu. Nieobecność na mszy niedzielnej nie będzie grzechem. Gazeta Prawna. Available online: https: / www.gazetaprawna.pl/artykuly/1459504,pinkas-koronawirus-kosciol-modlitwa-wdomu.html (accessed on 11 August 2020).

Gosc.pl. 2020. Abp Gądecki apeluje o korzystanie z dyspensy od uczestnictwa w niedzielnej mszy św. Gość Niedzielny. Available online: https:/ / www.gosc.pl/doc/6215081.Abp-Gadecki-apeluje-o-korzystanie-z-dyspensy-od-uczestnictwa-w (accessed on 13 August 2020).

Hashmi, Furqan K., Qaiser Iqbal, Naheed Haque, and Fahad Saleem. 2020. Religious Cliche and Stigma: A Brief Response to Overlooked Barriers in COVID-19 Management. Journal of Religion \& Health 59: 2697-700.

Hepp, Andreas. 2013. Mediatization. A panorama of media and communication research. In Mediatization and Sociolinguistic Change. Edited by Jannis Androutsopoulos. Berlin: de Gruyter, pp. 49-66.

Hepp, Andreas, Stig Hjarvard, and Knut Lundby. 2015. Mediatization: Theorizing the Interpaly between Media, Culture and Society. Media, Culture E Society 37: 314-24.

Hernández-Guerra, Concepción. 2014. An overview of the approaches and methods for analysing a text from a discursive viewpoint. Onomázein 30: 237-47. [CrossRef]

Hjarvard, Stig. 2008a. The mediatization of religion. A theory of the media as agents of religious change. Nordic Journal of Media Studies 6: 9-26. [CrossRef]

Hjarvard, Stig. 2008b. The Mediatization of Society. A Theory of the Media as Agents of Social and Cultural Change. Nordicom Review 29: 105-34.

Hoover, Stewart. 2002. The Culturalist Turn in Scholarship on Media and Religion. Journal of Media and Religion 1: 25-36. [CrossRef]

IB. 2020. Koronawirus w Polsce. Jest decyzja Episkopatu ws. mszy świętych. Fakt. Available online: https://www.fakt.pl/wydarzenia/ polska/koronawirus-w-polsce-jest-decyzja-episkopatu-ws-mszy-swietych/0p3x22c\#slajd-1 (accessed on 12 August 2020).

Idziemy.pl/mj. 2020a. Komunikat Arcybiskupa Metropolity Warszawskiego. Idziemy. Available online: http://idziemy.pl/kosciol/ komunikat-arcybiskupa-metropolity-warszawskiego/ 63443 (accessed on 3 August 2020).

Idziemy.pl/mj. 2020b. Transmisje Mszy św. z Jasnej Góry. Idziemy. Available online: http://idziemy.pl/kosciol/transmisje-mszy-sw-zjasnej-gory / 63440 (accessed on 3 August 2020).

Idziemy.pl/rm. 2020. Diecezje reaguja na komunikat KEP. Idziemy. Available online: http:/ /idziemy.pl/kosciol/diecezje-reaguja-nakomunikat-kep/63433 (accessed on 9 August 2020).

John Paul II. 2005. Apostolic Letter to those responsible for communications "The Rapid Development". Available online: http:/ /www. vatican.va/content/john-paul-ii/en/apost_letters/2005/documents/hf_jp-ii_apl_20050124_il-rapido-sviluppo.html (accessed on 3 September 2020).

JOSIE. 2020. Msze zostana odwołane? Gowin zabrał głos. Fakt. Available online: https://www.fakt.pl/wydarzenia/polityka/jaroslawgowin-rzad-nie-bedzie-narzucal-ograniczen-wspolnotom-religijnym/slylp4z (accessed on 2 August 2020).

Kamieniecki, Mariusz. 2020. Niech emocje nie wymykają się spod kontroli. Nasz Dziennik. Available online: https://naszdziennik.pl/ polska-kraj/217785,niech-emocje-nie-wymykaja-sie-spod-kontroli.html (accessed on 2 August 2020).

Kamiński, Romuald. 2020. Wobec Epidemii. Idziemy. Available online: http://idziemy.pl/kosciol/wobec-epidemii/63484 (accessed on 12 August 2020).

Kataryna. 2020. Małość w czasach zarazy. Wprost. Available online: http:/ /wprost.pl/tygodnik/10306693/malosc-w-czasach-zarazy. html (accessed on 6 August 2020).

Kołodziej, Beata. 2020. Kraków: Abp Jędraszewski apeluje o pozostanie w domach. Gazeta Prawna. Available online: https: / / www.gazetaprawna.pl/artykuly /1460115,biskup-plocki-apeluje-do-dzieci-mlodziezy-osob-starszych-i-chorycho-pozostanie-w-domach.html (accessed on 9 August 2020).

Konferencja Episkopatu Polski. 2017. Dyrektorium w sprawie Mszy św. transmitowanej przez telewizję. Akta Konferencji Episkopatu Polski 29: 48-55. 
Kromer, Oktawia, and Michał Wojtczuk. 2020. Koronawirus. Msza w Świątyni Opatrzności Bożej zostanie odwołana? “Sytuacja jest dynamiczna". Gazeta Wyborcza. Available online: https://warszawa.wyborcza.pl/warszawa/7,54420,25781383,koronawirusmsza-w-swiatyni-opatrznosci-bozej-zostanie-odwolana.html (accessed on 1 August 2020).

Krotz, Friedrich. 2003. Metaprozessesozialen und kulturellen Wandels und die Medien. Medien Journal 27: 7-19. [CrossRef]

Krzyżak, Tomasz. 2020a. Sondaż: Wierni zadowoleni z dyspensy. Rzeczpospolita. Available online: https://www.rp.pl/Kosciol/200319 463-Sondaz-Wierni-zadowoleni-z-dyspensy.html (accessed on 1 August 2020).

Krzyżak, Tomasz. 2020b. Krzyżak: Ostatni moment na katechezę. Rzeczpospolita. Available online: https://www.rp.pl/Komentarze/ 303169865-Krzyzak-Ostatni-moment-na-katecheze.html (accessed on 2 August 2020).

KS. 2020. Kościoły mogą zostać zamknięte. Deklaracja ministra Szumowskiego. Super Express. Available online: https://www.se.pl/ wiadomosci/polityka/koscioly-moga-zostac-zamkniete-deklaracja-ministra-szumowskiego-aa-rXfs-ZCVF-dqA6.html (accessed on 2 August 2020).

L24.lt. 2020. Prof. Grzegorz Kucharczyk o zamykaniu kościołów w obawie przed koronawirusem. Available online: http://124.lt/pl/ opinie-i-komentarze/item/338384-prof-g-kucharczyk-o-zamykaniu-kosciolow-w-obawie-przed-koronawirusem (accessed on 11 August 2020).

Langer, Roy. 1997. The Concept of Discourse in The Analysis of Complex Communication Events. Working Paper/Intercultural Communication and Management. København: Institut for Interkulturel Kommunikationog Ledelse, IKL, Copenhagen Business School, pp. $1-38$.

Levin, Jeff. 2020. The Faith Community and the SARS-CoV-2 Outbreak: Part of the Problem or Part of the Solution? Journal of Religion $\mathcal{E}$ Health 59: 2215-28.

Lisowska-Magdziarz, Małgorzata. 2004. Analiza zawartości mediów. Przewodnik dla studentów. Kraków: Uniwersytet Jagielloński.

Lövheim, Mia, and Evelina Lundmark. 2019. Gender, Religion and Authority in Digital Media. ESSACHESS. Journal for Communication Studies 12: 23-38.

mag. 2020. Bp Kamiński wydał dekret zawieszający nabożeństwa. Tygodnik Katolicki Niedziela. Available online: https://www. niedziela.pl/artykul/50208/Bp-Kaminski-wydal-dekret-zawieszajacy (accessed on 13 August 2020).

Makowski, Jarosław. 2020a. Ten dzień powinniśmy zapamiętać. W niedzielę polska wiara zderzyła się z koronawirusem. I co się okazało? Newsweek Polska. Available online: https:/ / www.newsweek.pl/polska/spoleczenstwo/koronawirus-w-polsce-jakpolska-katolicka-wiara-zderza-sie-z-koronawirusem/8rb558s (accessed on 11 August 2020).

Makowski, Jarosław. 2020b. Teolog Jarosław Makowski: trzeba zrezygnować z mszy z powodu koronawirusa. Fakt. Available online: https: / / www.fakt.pl/wydarzenia/polityka/jaroslaw-makowsk-koronawirus-i-kosciol/93j9gyf (accessed on 1 August 2020).

Mikołajczyk, Maciej. 2020. Szafarze zagłady. Tygodnik NIE. Available online: http://tygodniknie.pl/szafarze-zarazy/ (accessed on 11 August 2020).

Mikulski, Jakub, and Magdalena Zapart. 2020. Polska i świat walczą z koronawirusem-Relacja. Rzeczpospolita. Available online: https:/ / www.rp.pl/Koronawirus-2019-nCoV/200319485-Polska-i-swiat-walcza-z-koronawirusem---relacja.html (accessed on 3 August 2020).

Molga, Tomasz. 2020. Nie zamykać kościołów? Porażająca nauczka o koronawirusie z Korei. Chora poszła na mszę. Available online: https:/ / wiadomosci.wp.pl/nie-zamykac-kosciolow-porazajaca-nauczka-o-koronawirusie-z-korei-chora-poszla-namsze-6488199662930049a (accessed on 12 March 2020).

Muller, Maciej, and Andrzej Draguła. 2020. Komunia tez podlega prawom biologii. Tygodnik Powszechny. Available online: https: / / www.tygodnikpowszechny.pl/komunia-tez-podlega-prawom-biologii-162543 (accessed on 11 August 2020).

Nb. 2020. Onet, Wirtualna Polska i TVN24.pl będą transmitować niedzielną mszę świętą. Available online: https://www. wirtualnemedia.pl/artykul/onet-wirtualna-polska-tvn24-pl-transmisja-niedziela-msza-swieta (accessed on 13 March 2020).

Niedziela.pl. 2020. Transmisje Mszy św. z jasnogórskiej kaplicy Matki Bożej na portalu niedziela.pl. Tygodnik Katolicki Niedziela. Available online: https://www.niedziela.pl/artykul/50201/Transmisje-Mszy-sw-z-jasnogorskiej (accessed on 6 August 2020).

Niedziela.pl/tk. 2020. CBOS: 90 proc. Polaków deklaruje wiarę, przybywa niewierzacych. Tygodnik Katolicki Niedziela. Available online: https:/ / www.niedziela.pl/artykul/54296/CBOS-90-proc-Polakow-deklaruje-wiare (accessed on 6 July 2020).

Nowak, Artur. 2020. Diabły i triumfu Chrystusa nad zarazkami. Arcybiskup Dzięga napisał list o epidemii koronawirusa. Newsweek Polska. Available online: https:/ / www.newsweek.pl/opinie/arcybiskup-andrzej-dziega-napisal-list-o-epidemii-koronawirusa/ ljmvvqz (accessed on 6 August 2020).

Odrobińska, Monika. 2020. Wspólnota na łączach. Idziemy. Available online: http://idziemy.pl/kosciol/wspolnota-na-laczach (accessed on 6 August 2020).

Orłowski, Maciej, Rafał Wójcik, and Jakub Łukaszewski. 2020. Epidemia koronawirusa w Polsce i na świecie. Rząd przywraca granice. Rzeczpospolita. Available online: https: / / www.rp.pl/Koronawirus-2019-nCoV /200319485-Polska-i-swiat-walcza-zkoronawirusem---relacja.html (accessed on 3 August 2020).

Oxholm, Theis, Catherine Ricera, Kearly Schirrman, and Wiliam J. Hovers. 2020. New Zealand Religious Community Responses to COVID-19 While Under Level 4 Lockdown. Journal of Religion \& Health. [CrossRef]

Parish, Helena. 2020. The Absence of Presence and the Presence of Absence: Social Distancing, Sacraments, and the Virtual Religious Community during the COVID-19 Pandemic. Religions 11: 276. [CrossRef]

Pastwa, Rafał. 2020. Religious communication on the example of the Catholic Church in Poland including the context of the coronavirus pandemic. Kultura-Media-Teologia 41: 38-60. 
Pawlicka, Aleksandra. 2020. Polski Kościół i koronawirus. Duchowni zmienili rząd dusz na rząd tacy. Newsweek Polska. Available online: https://www.newsweek.pl/opinie/polski-kosciol-i-koronawirus-dlaczego-biskupi-zadzialali-tak-pozno/803j5ew (accessed on 2 August 2020).

Peterson, Kristin. 2019. Pushing boundaries and blurring categories in digital media and religion research. Sociology Compass 14: 1-11. [CrossRef]

Pięciak, Wojciech. 2020. W imię odpowiedzialności. Tygodnik Powszechny. Available online: https://www.tygodnikpowszechny.pl/wimie-odpowiedzialnosci-162544 (accessed on 2 August 2020).

Pisarek, Walery. 1983. Analiza zawartości prasy. Kraków: Ośrodek Badań Prasoznawczych.

POM. 2020. Kardynał Nycz wydał komunikat dotyczący uczestnictwa w mszach. Fakt. Available online: https://www.fakt.pl/ wydarzenia/polska/kardynal-nycz-wydal-komunikat-dotyczacy-uczestnictwa-w-mszach/cfpwdc5 (accessed on 6 August 2020).

Pontifical Council for Promoting the New Evangelization. 2020. Directory for Catechesis. Vatican City: Pontifical Council for Promoting the New Evangelization.

Pontifical Council for Social Communications. 2002. The Church and Internet. Available online: http://www.vatican.va/roman_curia/ pontifical_councils/pccs/documents/rc_pc_pccs_doc_20020228_church-internet_en.html (accessed on 23 October 2020).

pr/pap/bg. 2020. Rekordowe zainteresowanie mszami w telewizji. Available online: https://www.wirtualnemedia.pl/artykul/ rekordowe-zainteresowanie-mszami-w-telewizji (accessed on 14 March 2020).

Prymaspolski.pl. 2020. Available online: https:/ / prymaspolski.pl/dyspensa-dekret-prymasa-polski (accessed on 12 March 2020).

qm. 2020. O. Rydzyk: Zachowujmy odległość w kościele. Rzeczpospolita. Available online: https://www.rp.pl/Kosciol/200319473-ORydzyk-Zachowujmy-odleglosc-w-kosciele.html (accessed on 6 August 2020).

Radej, Maciej. 2020. „Mira sane ope Marconiana”. Pierwsze radiowe transmisje mszy świętych. Kultura-Media-Teologia 43: 88-101. [CrossRef]

Rivera, Paolo B. 2020. Religion and COVID 19 in Peru of the Bicentennial of the Republic. "Laicite" of Collaboration and Evangelical Reactions to the Pandemic. Estudos de Religiao 34: 431-62. [CrossRef]

Roso, Joseph, Anna Holleman, and Mark Chaves. 2020. Changing Worship Practices in American Congregations. Journal for the Scientific Study of Religion 59: 675-84. [CrossRef]

Ruether, Traci. 2019. Live Streaming vs. Traditional Live Broadcasting: What's the Difference. Available online: https://www.wowza. $\mathrm{com} / \mathrm{blog} /$ streaming-vs-cable-satellite-broadcasting (accessed on 6 August 2020).

Sikora, Piotr. 2020. Słowa biskupa błędne i groźne. Tygodnik Powszechny. Available online: https:/ /www.tygodnikpowszechny.pl/ slowa-biskupa-bledne-i-grozne-162565 (accessed on 2 August 2020).

sm. 2020. Codzienna msza św. w TV Republika. Gazeta Polska Codziennie. Available online: https://gpcodziennie.pl/128056 -codziennamszaswwtvrepublika.html (accessed on 6 August 2020).

Soukup, Paul. 2019. Some past meetings of communication, theology, and media theology. Kultura-Media-Teologia 38: 25-46.

Sporniak, Artur. 2020a. Kościelny egzamin z dojrzałości. Tygodnik Powszechny. Available online: https://www.tygodnikpowszechny. pl/koscielny-egzamin-z-dojrzalosci-162567 (accessed on 2 August 2020).

Sporniak, Artur. 2020b. Kościelna ewolucja wobec epidemii. Tygodnik Powszechny. Available online: https:/ /www.tygodnikpowszechny. pl/koscielna-ewolucja-wobec-epidemii-162630 (accessed on 1 August 2020).

Ssd. 2020. Duszpasterz gwiazd ks. Janusz Koplewski: Odwagi! Wirus to nie kara boska. Fakt. Available online: https://www.fakt.pl/ wydarzenia/polityka/ks-janusz-koplewski-o-koronawirusie/bp2zv98?srcc=ucs\&utm_v=2 (accessed on 2 August 2020).

Steinhagen, Dorota. 2020. Arcybiskup Wacław Depo: Koronawirus to tylko jedno z zagrożeń, nie najważniejsze, obok wojen i ideologii gender. Gazeta Wyborcza. Available online: https:/ / czestochowa.wyborcza.pl/czestochowa/7,48725,25778532,abp-waclaw-depokoronawirus-to-tylko-jedno-z-zagrozen-nie.html (accessed on 11 August 2020).

Stolfik-Binda, Justyna. 2020. Archidiecezja katowicka. Wszyscy objęci dyspensa od obowiązku uczestnictwa we Mszy św. Gość Niedzielny. Available online: https://www.gosc.pl/doc/6215622.Archidiecezja-katowicka-Wszyscy-objeci-dyspensa-odobowiazku (accessed on 1 August 2020).

Strömbäck, Jesper. 2008. Four phases of mediatization: An analysis of the mediatization of politics. The International Journal of Press/Politics 13: 228-46. [CrossRef]

Szczepaniak, Maciej. 2012. Radiowa transmisja mszy św. z Kongresu Eucharystycznego w Dublinie. Przełom w recepcji transmisji radiowych w praktyce eklezjalnej. Kultura-Media-Teologia 9: 8-19.

Szczepaniak, Maciej. 2013. Msza fonogeniczna. Pierwsza polska radiowa transmisja mszy świętej i towarzyszące jej okoliczności. Poznań: Wydawnictwo Wydziału Teologicznego Uniwersytetu im. Adama Mickiewicza w Poznaniu.

Szostkiewicz, Adam. 2020. Wyzwania dla wiary i polskiego Kościoła w czasie zarazy. Polityka. Available online: https:/ /www.polityka. pl/tygodnikpolityka/spoleczenstwo/1945962,1,wyzwania-dla-wiary-i-polskiego-kosciola-w-czasie-zarazy.read (accessed on 1 August 2020).

Szułdrzyński, Michał. 2020. Michał Szułdrzyński: Góry antykatolickiego obskurantyzmu. Rzeczpospolita. Available online: https: //www.rp.pl/Komentarze/200319643-Michal-Szuldrzynski-Gory-antykatolickiego-obskurantyzmu.html (accessed on 6 August 2020).

Tabaka, Michał. 2020. Przedsiębiorcy wściekli. Rząd kazał im zamknąc zakłady, a do kościołów wpuszcza 50 osób. Available online: https://spidersweb.pl/bizblog/przedsiebiorcy-koscioly-wielkanoc/ (accessed on 3 April 2020). 
teka. 2020. Zakażona kobieta poszła na mszę. Efekt? Setki zakażonych! Fakt. Available online: https://www.fakt.pl/wydarzenia/ swiat/korea-poludniowa-zakazona-kobieta-poszla-na-msze-efekt-wybuchla-epidemia/v75gn7v (accessed on 2 August 2020).

teka, msob, and pom. 2020. Epidemia koronawirusa. Rośnie liczba chorych w Polsce. Fakt. Available online: https://www.fakt.pl/ wydarzenia/polska/koronawirus-w-polsce-relacja-na-zywo-zmarla-druga-ofiara-epidemii/mlndnn8 (accessed on 2 August 2020).

UZ. 2020a. Gdzie jest Jarosław Kaczyński? Prezesa PiS widziano na niedzielnej mszy. Gazeta.pl. Available online: https://wiadomosci. gazeta.pl/wiadomosci/7,173952,25792757,gdzie-jest-jaroslaw-kaczynski-prezesa-pis-widziano-na-niedzielnej.html (accessed on 2 August 2020).

UZ. 2020b. Rzecznik Episkopatu: Niewyobrażalne jest, by wierni nie modlili się w kościołach. Gazeta Wyborcza. Available online: https:/ / wiadomosci.gazeta.pl/wiadomosci/7,114883,25778802,rzecznik-episkopatu-niewyobrazalne-jest-by-wierni-niemodlili.html (accessed on 11 March 2020).

UZ. 2020c. Koronawirus. Kard. Kazimierz Nycz zwolnił wiernych z obowiązku udziału w niedzielnej mszy świętej. Gazeta Wyborcza. Available online: https:/ / wiadomosci.gazeta.pl/wiadomosci/7,173952,25786650,koronawirus-kard-kazimierz-nycz-zwolnilwiernych-z-obowiazku.html (accessed on 3 August 2020).

van Dijk, Teun A. 1993. Principles of critical discourse analysis. Discourse E Society 4: 249-83.

van Dijk, Teun A. 2005. Critical discourse analysis. In The Handbook of Discourse Analysis. Edited by Deborah Schiffrin, Deborah Tannen and Heidi E. Hamilton. Oxford: Blackwell Publishers Ltd., pp. 349-71.

van Dijk, Teun A. 2006. Badania nad dyskursem. In Wspótczesne teorie socjologiczne. Edited by Aleksandra Jasińska-Kania. Warszawa: Scholar, t. 2. pp. 1020-46.

Vatican Council II. 1965. Pastoral Constitution on the Church in the Modern Word „Gaudium et spes”. Available online: http:/ /www. vatican.va/archive/hist_councils/ii_vatican_council/documents/vat-ii_const_19651207_gaudium-et-spes_en.html (accessed on 23 October 2020).

Vermeer, Paul, and Joris Kregting. 2020. Religion and the Transmission of COVID-19 in The Netherlands. Religions 11: 393. [CrossRef]

Wanat, Ewa. 2020. Idzie zaraza, alleluja! Wprost. Available online: https://www.wprost.pl/tygodnik/10306688/idzie-zaraza-alleluja. html (accessed on 2 August 2020).

Widacki, Jan. 2020. „Silni, zwarci, gotowi” i ,jakoś to będzie”. Tygodnik Przegląd. Available online: hhttps://www.tygodnikprzeglad. $\mathrm{pl} /$ silni-zwarci-gotowi-jakos-bedzie/ (accessed on 1 August 2020).

Wilgocki, Michał. 2020. Apel do Episkopatu: Bądźmy solidarni w obliczu koronawirusa. Gazeta Wyborcza. Available online: https: / / wyborcza.pl/7,75968,25783033,apel-do-episkopatu-badzmy-solidarni-w-obliczu-koronawirusa.html (accessed on 1 August 2020).

Wolski, Marcin. 2020. Wirus kontra sacrum. Gazeta Polska. Available online: https:/ /www.gazetapolska.pl/21901-wirus-kontra-sacrum (accessed on 2 August 2020).

Wprost.pl. 2020. Msze święte. Gdzie oglądać w telewizji i internecie? Wprost. Available online: https://www.wprost.pl/kraj/103067 90/msze-swiete-gdzie-ogladac-w-telewizji-i-internecie.html (accessed on 9 August 2020).

Wyborcza.pl. 2020. Kościół Transmisja mszy świętej. Parafia bł. Edwarda Detkensa w Lesie Bielańskim. Gazeta Wyborcza. Available online: https:/ / wyborcza.pl/7,82983,25790634,transmisja-mszy-swietej-parafia-bl-edwarda-detkensa-w-lesie.html (accessed on 11 August 2020).

Zaremba, Maciej. 2020. Gdańska kuria: Seniorzy i chorzy mogą w niedzielę zostać w domu śledząc transmisje mszy świętej. Wprost. Available online: https://zdrowie.wprost.pl/koronawirus/10306132/gdanska-kuria-seniorzy-i-chorzy-moga-w-niedzielezostac-w-domu-sledzac-transmisje-mszy-swietej.html (accessed on 2 August 2020). 